\title{
総義歯における人工臼蒾の咬合面形態の相違に よる咀嚼力および咬合力に関する研究
}

第 2 報 $20^{\circ}$ 咬頭人工臼歯について

鍵谷隆一

\author{
Studies on Mastication and Biting Forces of \\ Differences from Occlusal Form of Artificial \\ Posterior Teeth of Complete Dentures
}

Part 2. 20 Degree cusp Teeth

\author{
Ryuichi Kagiya
}

\footnotetext{
$<$ 目 次 $>$

第 1 章 緒 言

第 2 章 材料および方法

第 1 節 被験者および被験総義歯

第 2 節 測定装圏および測定方法

第 3 章 成 績

第 1 節 咬合力

第 2 節 咬合力と筋電図

第 3 節 咀嚼力と対合力

第 4 節 咀嚼力と筋電図

第 4 章 総括および検討

第 5 章 結 論

文献
}

\section{第 1 章 緒 㖣}

総義歯補緅学に扔いて，人工臼歯の咬合面形態が咀嚼 機能に大きな影響を与えることが古くから注目され，多 くの研究者 ${ }^{120)}$ によってその形態の基本的条件が種々検

日本大学大学院歯学研究科歯科補緅学尃攻（指導：中沢 媇教授)

Nihon University Graduate School of Dentistry (Major in Prosthodontics) (Director: Prof. Yasushi Nakazawa)

昭和 53 年 11 月 6 日受付
討されてきた. しかし現在この点について必ずしも基準 があるとは考えられない.

人工自歯の咀嚼機能を判定する定量的方法には，子

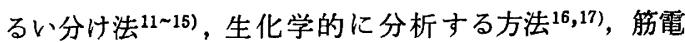
図による方法 ${ }^{18-24)}$ および咬合力と咀嚼力を測定する方 法25 31)などがある。

そこで著者は，人工臼歯の咬合面形態の相違が，総義 歯装着者の咀嚼機能にどのように影響するかを解明する

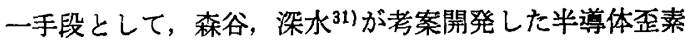
子を応用した咬合力・咀嚼力測定装置を，咬合面形態の 異なる総義歯の上顎第 1 大臼歯部に使用し，各下頡位で の咬合力，咀嚼力，曣下期における対合力およびこの間 における左右の咬筋と側頭筋との筋電図を同時記録した ので報告する.

\section{第 2 章 材料および方法}

\section{第 1 節＼cjkstart被験者および被験総義迷 被験者}

被験者は日本大学歯科病院の外来総義歯装着者の中か ら選んだ総義歯装着年数 5〜10 年で, 50 歳代の男性 6 名で次のような条件 ${ }^{32}$ を備えた者である. すなわち踖床 上, 䫟関節, 下顎運動および咀嚼機能に障害を及ぼすよ うな既往歴および現症が認められず，診査の結果，上下 顎堤頂の矢状的および水平的対位関係は平行型，上下顎 堤形態は上顎平均型対下顎平均型，上下顎粘膜の被圧縮 


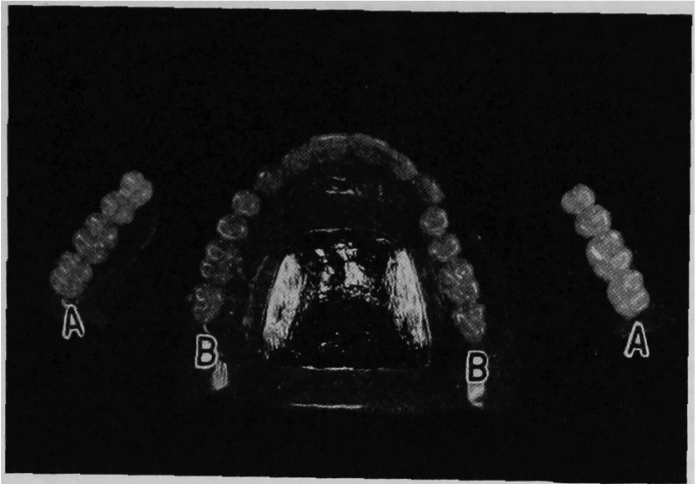

図 1 完成した上顎被験者総義苗

(A: $30^{\circ}$ 人工白歯, B : $20^{\circ}$ 人工臼歯 被験者 : G.T.)

状態は上頡標準型対下颖標準型で，義歯床面積は上頡中 型対下顥中型に属するものである.

\section{被験総義歯}

久松 ${ }^{30)}$ の方法に従い， $30^{\circ}$ 咬頭人工臼歯を使用した被 験総義菌 (以下 $30^{\circ}$ 人工四歯と略す) を Dentatus 咬合 器 (ARL 型) にて調製し, 対照とした（図 1-A，図 2A). $20^{\circ}$ 咬頭人工臼菌を用いた被験総義菌（以下 $20^{\circ}$ 人 工臼歯と略す）の調製は，30。土正歯を使用した被験 総義歯の咬合高径および上下澦前歯部を変えることなく 兒歯部を $20^{\circ}$ 人工臼歯に取り替え， $20^{\circ}$ 人工臼歯を bilateral balanced occulusionにて排列して被験総義歯を 調製した（図 1-B，図 2-B). なお，30人歯には Dentsply 社製 Pilkington-Turner vacuum fired $30^{\circ}$ posteriors (230M)，20 人工臼菌には Dentsply 社製 Trubyte vacuum fired $20^{\circ}$ posteriors (29M) を使用 した.

\section{第 2 節 測定装置および測定方法}

咀嚼力, 咬合力の測定, 筋電図の観察, 咬合力の測定 と笳電図パターンの観察および咀嚼時における咀嚼力の 测定と筋電図パターンの観察は, 深水 ${ }^{27)}$, 志田 ${ }^{28)}$, 遠藤 ${ }^{29)}$ および久松 ${ }^{30)}$ の装置と方法に従い，筋電図の判定程度は $200 \mu \mathrm{V}$ 以上を強度 (H)，200 $50 \mu \mathrm{V}$ を中等度 (H) および $50 \mu \mathrm{V}$ 以下を軽度 (十) とした.

測定は，各被験者ごとに $30^{\circ}$ 人工臼歯を装着して 3 力 月経過後，総義歯が口腔になじんで顎粘膜および周囲組 織に何ら障害がなく満足して咀嚼機能を営んでいる状態 において，1 日 3 回各週ごとに計 9 回測定し，その後 $20^{\circ}$ 人工妇歯に交換して，1 力月経過後 $30^{\circ}$ 人工臼歯と同様 に测定した.

以上の各項目についての平均值を求め，さらに全被験

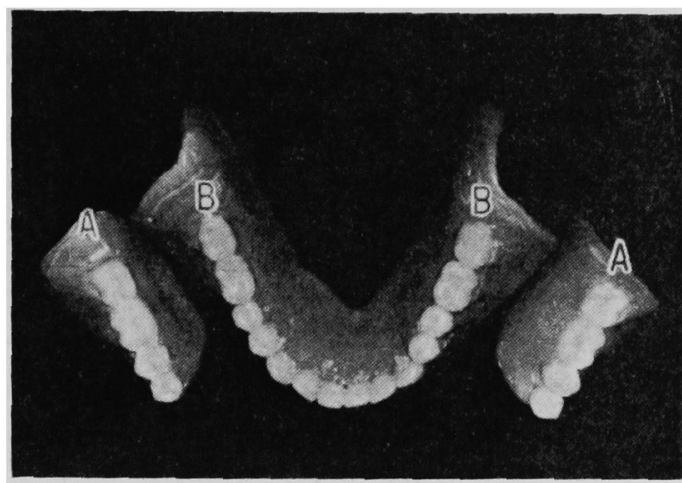

図 2 完成した下影被験者総義蔝

(A : $30^{\circ}$ 人工臼歯, B : $20^{\circ}$ 人工田宷 被験者 : G.T.)

者についての平均值を求めた. その平均値と母平均值か ら信頼限界（ $\alpha=0.05 ）$ を求め有意判定を行った。

\section{第 3 章 成 綪}

\section{第 1 節 咬合力}

各下顎位における，上顎第 1 大臼歯部の咬合力とその 活動開始時間との左右差は表 1 および 2 に示すとおりで ある.

各下頡位に拈ける咬合力は， $30^{\circ}$ 人工齿の方が $20^{\circ}$ 人工臼歯より大きく，とくに側方咬合位の作業側および 前方咬合位の右側において，有意であった。

左右の咬合力の活動開始時間の側差は、いずれの人工 臼歯とも側方咬合位の作業側と前方咬合位の右側に早い 傾向を衿めた。

\section{第 2 節 咬合カと筋電図}

各下顎位における咬合力と咬笳および側頭筋の活動様 式は表 1，2 および図 3１0 に示すごとくである.

能の放電状態をみると，咬頭嵌合位に拉いて，30⼈ 工F歯と $20^{\circ}$ 人工F歯は 4 笳ともに活発な放電活動で, そして典型的な démblée 型の様相を示す活動様式であ った．側方咬合位において，両人工臼歯はともに，作業 側で活発な放電活動を示し, さらに $20^{\circ}$ 人工臼歯の方が より強い放電活動を示した，前方咬合位において，両人 工白歯はほぼ同じ放電状態を示し，とくに $20^{\circ}$ 人工兒歯 で咬筋が中等度〜強度であった。

筋の放電開始をみると各下筊位において，両人工臼歯 は 4 筋ともに咬合力の活動開始より早かった。 
表 $130^{\circ}$ 人工臼齔の各下颚位における咬合力と筋電図とに関する測定所見

\begin{tabular}{|c|c|c|c|c|c|}
\hline & & 咬頭嵌获位 & 应㑡方咬合位 & 右 㑡方咬 合位 & 前方 咬 合 位 \\
\hline \multirow{2}{*}{ 咬 合 力 $(\mathrm{kg})$} & $L$ & $14.4(13.3 \sim 15.5)$ & $13.4(12.6 \sim 14.2)$ & $7.9(6.9-8.9)$ & $5.0(3.9 \sim 6.1)$ \\
\hline & $\mathrm{R}$ & $14.9(13.9 \sim 15.9)$ & $8.1(6.9 \sim 9.3)$ & $14.0(12.8 \sim 15.2)$ & $6.1(4.9 \sim 7.3)$ \\
\hline $\begin{array}{l}\begin{array}{l}\text { 咬合力活動開始時間の } \\
\text { 差 } \quad(\mathrm{sec})\end{array} \\
\end{array}$ & & $(\longrightarrow .00$ & $\begin{array}{l}\text { (1)*0.07 } \\
(0.05 \sim 0.09)\end{array}$ & $\begin{array}{l}\text { (B) } 0.08 \\
(0.04 \sim 0.12)\end{array}$ & $\begin{array}{l}\text { (1) } 0.02 \\
(0.00 \sim 0.04)\end{array}$ \\
\hline \multirow{4}{*}{ 筋 の 放 霍 状 態 } & L.M. & $H \star$ & \# & H & H \\
\hline & L.T. & H & H & + & + \\
\hline & R.M. & H & + & H & H \\
\hline & R.T. & \# & + & H & + \\
\hline \multirow{4}{*}{ 店在の咬筋および側貊 } & L.M. & $(\longrightarrow$ & $\begin{array}{c}0.06 \\
(0.03 \sim 0.09)\end{array}$ & $\begin{array}{c}0.05 \\
(0.03 \sim 0.07)\end{array}$ & $(-0.00$ \\
\hline & L.T. & $(\longrightarrow .00$ & $(\longrightarrow .00$ & $\begin{array}{c}0.07 \\
(0.05 \sim 0.09) \\
\end{array}$ & $\begin{array}{c}0.08 \\
(0.04 \sim 0.12) \\
\end{array}$ \\
\hline & R.M. & $(-0.00$ & $\begin{array}{c}0.04 \\
(0.02 \sim 0.06) \\
\end{array}$ & $(\stackrel{0.00}{\longrightarrow})$ & $(\stackrel{0.00}{\longrightarrow})$ \\
\hline & R.T. & $(-0.00$ & $\begin{array}{c}0.08 \\
(0.05 \sim 0.11)\end{array}$ & $\begin{array}{c}0.04 \\
(0.02 \sim 0.06) \\
\end{array}$ & $\begin{array}{c}0.09 \\
(0.04 \sim 0.12) \\
\end{array}$ \\
\hline \multirow[t]{2}{*}{$\frac{\lfloor}{\text { 咬合力と } 4 \text { 筋の放们と }}$} & L.M. & $\begin{array}{c}-0.12 \star \star \star \\
(-0.15 \sim-0.09) \\
\end{array}$ & $\begin{array}{c}-0.06 \\
(-0.08 \sim-0.04) \\
\end{array}$ & $\begin{array}{c}-0.15 \\
(-0.19 \sim-0.11) \\
\end{array}$ & $\begin{array}{c}-0.09 \\
(-0.11 \sim-0.07) \\
\end{array}$ \\
\hline & L.T. & $\begin{array}{c}-0.12 \\
(-0.15 \sim-0.09) \\
\end{array}$ & $\begin{array}{c}-0.12 \\
(-0.16 \sim-0.08) \\
\end{array}$ & $\begin{array}{c}-0.13 \\
(-0.16 \sim-0.11) \\
\end{array}$ & $\begin{array}{c}-0.01 \\
(-0.04 \sim 0.02) \\
\end{array}$ \\
\hline \multirow{2}{*}{ の差 ～（sec） } & R.M. & $\begin{array}{c}-0.12 \\
(-0.15 \sim-0.09) \\
\end{array}$ & $\begin{array}{c}-0.08 \\
(-0.10 \sim-0.06) \\
\end{array}$ & $\begin{array}{c}-0.20 \\
(-0.24--0.17) \\
\end{array}$ & $\begin{array}{c}-0.09 \\
(-0.11 \sim-0.07) \\
\end{array}$ \\
\hline & R.T. & $\begin{array}{c}-0.12 \\
(-0.15 \sim-0.09) \\
\end{array}$ & $\begin{array}{c}-0.04 \\
(-0.06 \sim-0.02) \\
\end{array}$ & $\begin{array}{c}-0.16 \\
(-0.19 \sim-0.12) \\
\end{array}$ & $\begin{array}{c}0.00 \\
(-0.04-0.04) \\
\end{array}$ \\
\hline \multirow[t]{2}{*}{$\frac{6\rfloor}{\text { 咬台力と } 4 \text { 筋の放篗と }}$} & L.M. & $\begin{array}{c}-0.12 \\
(-0.15 \sim-0.09) \\
\end{array}$ & $\begin{array}{c}-0.13 \\
(-0.15 \sim-0.11) \\
\end{array}$ & $\begin{array}{c}-0.07 \\
(-0.09 \sim-0.05) \\
\end{array}$ & $\begin{array}{c}-0.07 \\
(-0.09 \sim-0.03) \\
\end{array}$ \\
\hline & L.T. & $\begin{array}{c}-0.12 \\
(-0.15 \sim-0.09) \\
\end{array}$ & $\begin{array}{c}-0.19 \\
(-0.23 \sim-0.16) \\
\end{array}$ & $\begin{array}{c}-0.05 \\
(-0.08 \sim-0.02) \\
\end{array}$ & $\begin{array}{c}0.01 \\
(-0.01 \sim 0.03)\end{array}$ \\
\hline の開におけるる開始時開 & R.M. & $\begin{array}{c}-0.12 \\
(-0.15--0.09) \\
\end{array}$ & $\begin{array}{c}-0.15 \\
(-0.19 \sim-0.11) \\
\end{array}$ & $\begin{array}{c}-0.12 \\
(-0.16--0.08) \\
\end{array}$ & $\begin{array}{c}-0.07 \\
(-0.09 \sim-0.05) \\
\end{array}$ \\
\hline の差 （sec） & R.T. & $\begin{array}{c}-0.12 \\
(-0.15 \sim-0.09)\end{array}$ & $\begin{array}{c}-0.11 \\
(-0.13 \sim-0.09)\end{array}$ & $\begin{array}{c}-0.08 \\
(-0.10 \sim-0.05)\end{array}$ & $\begin{array}{c}0.02 \\
(-0.01 \sim 0.05)\end{array}$ \\
\hline
\end{tabular}

注：米：OのL(左側)あるい $\mathrm{R}$ (右側)は咬合力活動 開始の先行を示す

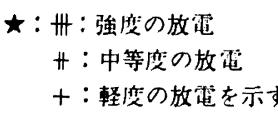

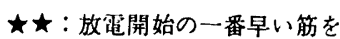
基準 $(0)$ として基準から の時閒差を示す
$+:$ 咬台力の活動開始が先行 - : 筋の放電開始が先行

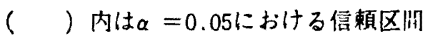

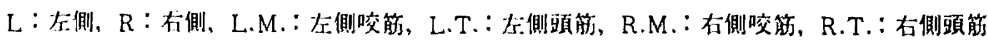


表 $220^{\circ}$ 人工毛歯の各下矤位における咬合力と筋電図とに関する測定所見

\begin{tabular}{|c|c|c|c|c|c|}
\hline & & 咬 頭 嵌 合 位 & 左側方 咬台位 & 右側方咬全位 & 狱方咬 合位 \\
\hline \multirow{2}{*}{ 咬 合 力 $(\mathrm{kg})$} & L. & $12.6(11.7 \sim 13.5)$ & $10.1(9.2-11.0)$ & $5.8(4.5-6.1)$ & $3.2(2.5 \sim 3.9)$ \\
\hline & R. & $13.8(12.5 \sim 15.2)$ & $6.9(5.7 \sim 8.1)$ & $11.0(9.4-12.6)$ & $4.0(3.4 \sim 4.6)$ \\
\hline $\begin{array}{l}\text { 咬合力活動開始時間の } \\
\text { 差 } \quad(\mathrm{sec})\end{array}$ & & $\left(\frac{0.00}{}\right)$ & $\begin{array}{l}(1) 0.06 \\
(0.04-0.08 ?\end{array}$ & (R) $\begin{array}{c}0.06 \\
(0.03 \sim 0.08)\end{array}$ & $\begin{array}{l}\text { B } \quad 0.03 \\
(0.01 \sim 0.06)\end{array}$ \\
\hline \multirow{4}{*}{ 筋 の 放 电状 態 } & L.M. & \# & HI & + & $H \sim H$ \\
\hline & L.T. & H & \# & $+-\pi$ & + \\
\hline & R.M. & 冊 & $+\sim H$ & H & $+\sim \#$ \\
\hline & R. T. & H & + & H & + \\
\hline \multirow{2}{*}{ 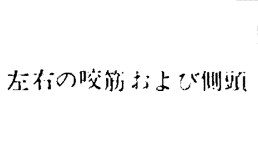 } & L.M. & $(\longrightarrow .00 \star \star$ & $\begin{array}{c}0.04 \\
(0.01 \sim 0.07)\end{array}$ & $\begin{array}{c}0.05 \\
(0.03 \sim 0.07)\end{array}$ & $(-0.00$ \\
\hline & L.T. & 0.00 & $(-0.00$ & $\begin{array}{c}0.07 \\
(0.02 \sim 0.12)\end{array}$ & $\begin{array}{c}0.05 \\
(0.03 \sim 0.07)\end{array}$ \\
\hline \multirow{2}{*}{ 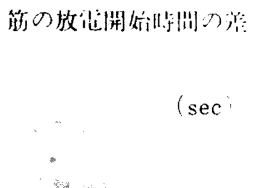 } & R.M. & $\left(\frac{0.00}{2}\right)$ & $\begin{array}{c}0.04 \\
(0.02 \sim 0.06)\end{array}$ & $(\longrightarrow$ & $(\longrightarrow$ \\
\hline & R.T. & $(1.00$ & $\begin{array}{c}0.08 \\
(0.05 \sim 0.11)\end{array}$ & $\begin{array}{c}0.06 \\
(0.01 \sim 0.12)\end{array}$ & $\begin{array}{c}0.05 \\
(0.03 \sim 0.07)\end{array}$ \\
\hline \multirow{2}{*}{ 咬公力上 4 筋の放他上 } & L.M. & $\begin{array}{r}-0.14 \star \star \star \\
(-0.15--0.12\end{array}$ & $\begin{array}{c}-0.09 \\
(-0.11--0.07)\end{array}$ & $\begin{array}{c}-0.14 \\
(-0.18 \sim-0.10)\end{array}$ & $\begin{array}{c}-0.08 \\
(-0.10 \sim-0.06)\end{array}$ \\
\hline & L.T. & $\begin{array}{c}-0.14 \\
(-0.15--0.12 \\
\end{array}$ & $\begin{array}{c}-0.12 \\
(-0.15 \sim-0.09\end{array}$ & $\begin{array}{c}-0.12 \\
(-0.16 \sim-0.08)\end{array}$ & $\begin{array}{c}-0.03 \\
(-0.05--0.01)\end{array}$ \\
\hline の閑にむふ汁る開始时洲 & R. M. & $\begin{array}{c}-0.14 \\
(-0.15 \sim-0.12)\end{array}$ & $\begin{array}{c}-0.08 \\
(-0.11 \sim-0.05\end{array}$ & $\begin{array}{c}-0.19 \\
(-0.23 \sim-0.15)\end{array}$ & $\begin{array}{c}-0.08 \\
(-0.10 \sim-0.06)\end{array}$ \\
\hline の) (sec) & R.T. & $\begin{array}{c}-0.14 \\
(-0.15 \sim-0.12)\end{array}$ & $\begin{array}{c}-0.04 \\
(-0.07 \sim-0.01)\end{array}$ & $\begin{array}{c}-0.14 \\
(-0.18 \sim-0.09)\end{array}$ & $\begin{array}{c}-0.04 \\
(-0.06 \sim-0.01)\end{array}$ \\
\hline \multirow[t]{2}{*}{ 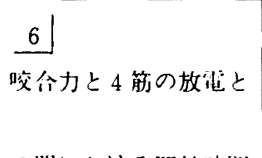 } & L.M. & $\begin{array}{c}-0.14 \\
(-0.15 \sim-0.12)\end{array}$ & $\begin{array}{c}-0.15 \\
(-0.18 \sim-0.13)\end{array}$ & $\begin{array}{c}-0.08 \\
(-0.13 \sim-0.03)\end{array}$ & $\begin{array}{c}-0.05 \\
(-0.07 \sim-0.03)\end{array}$ \\
\hline & $\mathrm{L} . \mathrm{T}$. & $\begin{array}{c}-0.14 \\
(-0.15 \sim-0.12)\end{array}$ & $\begin{array}{c}-0.19 \\
(-0.22 \sim-0.15) \\
\end{array}$ & $\begin{array}{c}-0.06 \\
(-0.10 \sim-0.01) \\
\end{array}$ & $\begin{array}{c}-0.00 \\
(-0.02 \sim 0.02)\end{array}$ \\
\hline の閐における開始時䦌 & R.M. & $\begin{array}{c}-0.14 \\
(-0.15 \sim-0.12) \\
\end{array}$ & $\begin{array}{c}-0.15 \\
(-0.18 \sim-0.11)\end{array}$ & $\begin{array}{c}-0.13 \\
(-0.18--0.07)\end{array}$ & $\begin{array}{c}-0.05 \\
(-0.07 \sim 0.03)\end{array}$ \\
\hline の差 （ & R.T. & $\begin{array}{c}-0.14 \\
(-0.15 \sim-0.12)\end{array}$ & $\begin{array}{c}-0.11 \\
(-0.13 \sim-0.09)\end{array}$ & $\begin{array}{c}-0.07 \\
(-0.09 \sim-0.05)\end{array}$ & $\begin{array}{c}-0.01 \\
(-0.04-0.02)\end{array}$ \\
\hline
\end{tabular}




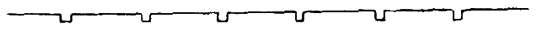

L.M.

L.T.

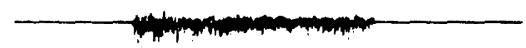

R.M.
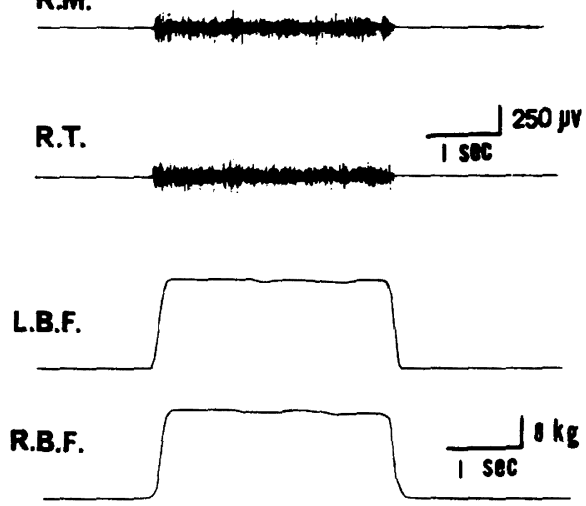

図 $330^{\circ}$ 人工臼歯の咬頭嵌合位における咬合力 と筋の放電 (被験者 : G.T.)

注 : L.B.F. : 左側方咬合力 R.B.F. : 右側方咬合力 L.M. : 左側咬能 L.T. : 左側側頭筋

R.M. : 右側咬觔 R.T. : 右側側頭笳

\section{L.M.}

L.T.

\section{R.M.}

R.T. $\mathrm{J} \mathrm{Sec}^{\mathrm{Sec}} 250 \mathrm{\mu v}$

L.B.F.
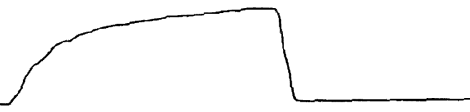

R.B.F.

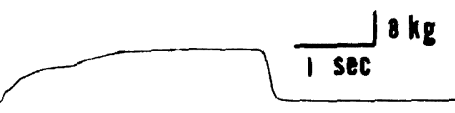

図 $430^{\circ}$ 人工臼歯の左侧方咬合位における咬合力 と笳の放電 (被験者: G.T.)

注 : 図 3 下注参照
L.M.

L.T.

RM.
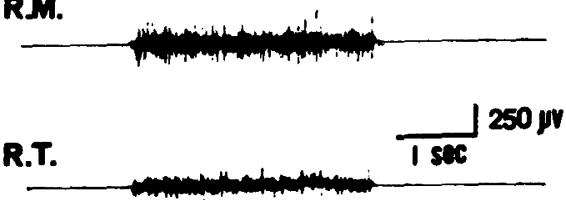

\section{L.B.F.}

R.B.F.

図 $530^{\circ}$ 人工自噛の右側方咬合位における咬合力 と笳の放電 (被験者 : G.T.)

注 : 図 3 下注参照

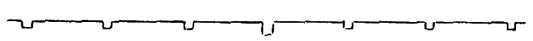

L.M.

L.T.

R.M.

R.T. $250 \mu v$
L.B.F.

R.B.F. $\frac{18 \mathrm{~kg}}{1 \mathrm{sec}}$

図 $630^{\circ}$ 人工臼歯の前方咬合位にお污咬合力上 肪の放電 (被験者 : G.T.)

注 : 图 3 下注参照 


\section{L.M.}

L.T.

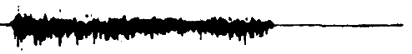

RA.
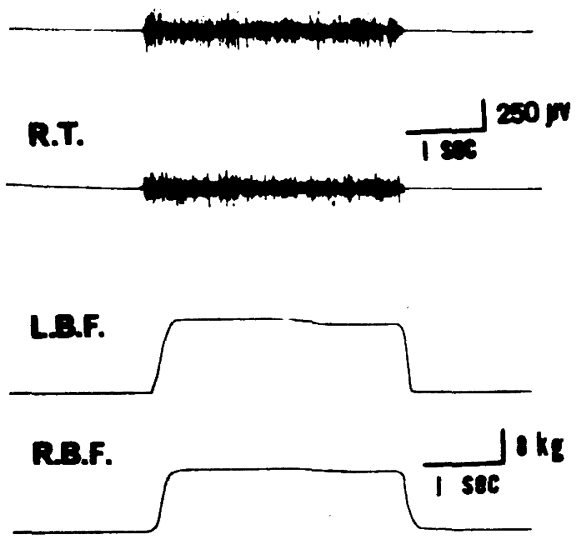

图 $720^{\circ}$ 人工臼歯の咬頭嵌合位における咬合力と 能の放電 (被験者 : G.T.)

注 : 図 3 下注参照

2

L.M.

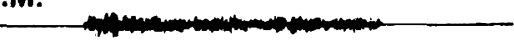

L.T.

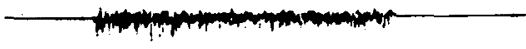

\section{R.M.}

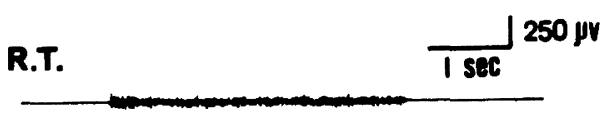

\section{L.B.F.}
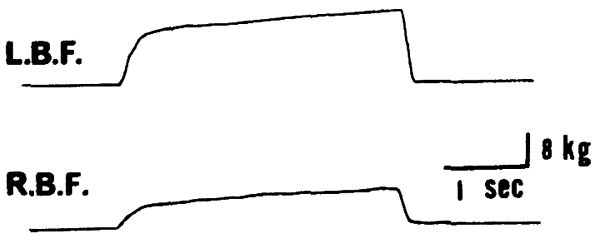

図 $820^{\circ}$ 人工臼齒の左側方咬合位における咬合力 と管の放電（被験者：G.T.)

注 : 図 3 下注参照
L.M.

L.T.

R.M.

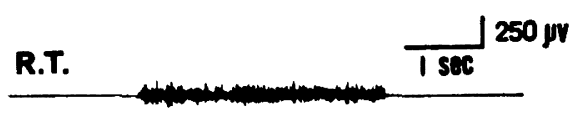

\section{L.B.F.}

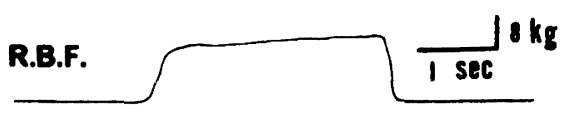

図 $920^{\circ}$ 人工毛歯の右側方咬合位における咬合力 と筋の放電 (被験者 : G.T.)

注 : 図 3 下注参照

\section{L.M.}

L.T.

R.M.

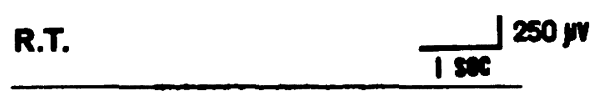

\section{L.B.F.}

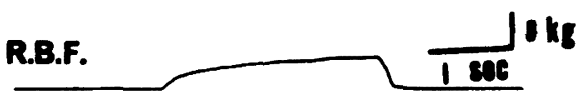

図 $1020^{\circ}$ 人工臼歯の前方咬合位における咬合力上 筋の放電 (被験者 : G.T.)

注 : 図 3 下注参照 


\begin{tabular}{|c|c|c|c|c|c|c|c|}
\hline & 体闻 & 期 & 期 & 期 & 期 & 期 & 䓵 下 期 \\
\hline \multirow{2}{*}{ ピーナッッ } & L & $9.0(7.0 \sim 11.1)$ & $11.5(10.1 \sim 12.8)$ & $12.2(10.3 \sim 14.1)$ & $10.7(9.2 \sim 12.1)$ & $9.2(7.9 \sim 10.5)$ & $6.2(4.7-7.7)$ \\
\hline & $\mathrm{R}$ & $9.3(8.0 \sim 10.5)$ & $12.2(10.6 \sim 13.8)$ & $12.8(11.5 \sim 14.2)$ & $11.0(9.7 \sim 12.4)$ & $9.3(8.0 \sim 10.5)$ & $6.1(4.8-7.4)$ \\
\hline \multirow{2}{*}{ 八 ム } & L & $6.9(5.7-8.1)$ & $8.3(7.0-9.6)$ & $11.4(9.9 \sim 12.8)$ & $10.6(9.5 \sim 11.7)$ & $9.2(7.8 \sim 10.5)$ & $4.9(3.3 \sim 6.6)$ \\
\hline & $\mathrm{R}$ & $7.8(6.1 \sim 9.4)$ & $9.5(8.6 \sim 10.4)$ & $11.8(10.6 \sim 13.3)$ & $10.9(9.8 \sim 12.0)$ & $8.3(6.8 \sim 9.7)$ & $6.2(4.3 \sim 8.0)$ \\
\hline \multirow{2}{*}{ タクアン } & $L$ & $8.6(6.6 \sim 9.2)$ & $12.7(11.0 \sim 14.4)$ & $12.7(10.4 \sim 15.0)$ & $10.2(8.6 \sim 11.9)$ & $10.3(8.5 \sim 12.1)$ & $5.2(3.5 \sim 7.0)$ \\
\hline & $\mathrm{R}$ & $8.4(7.1 \sim 9.7)$ & $12.0(10.3 \sim 13.5)$ & $11.0(9.8 \sim 12.2)$ & $11.1(10.0 \sim 12.3)$ & $9.5(8.0 \sim 11.0)$ & $6.4(5.0 \sim 7.8)$ \\
\hline
\end{tabular}

注：L：左㑡, $R$ ：右側，( )内の数字は信頼区間 $(\alpha=0.05)$ を示古.

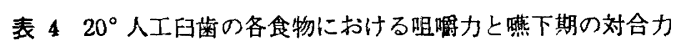

(単位: $\mathrm{kg}$ )

\begin{tabular}{|c|c|c|c|c|c|c|c|}
\hline & 休爵期 & 期 & 期 & 期 & 期 & 期 & 嚾 \\
\hline \multirow{2}{*}{ ピーナッッ } & L & $11.1(9.9 \sim 12.4)$ & $13.7(13.1 \sim 16.5)$ & $16.0(14.4 \sim 17.6)$ & $14.4(13.1 \sim 15.8)$ & $11.4(10.2 \sim 12.7)$ & $3.5(3.0-4.0)$ \\
\hline & $\mathrm{R}$ & $10.5(9.0 \sim 12.0)$ & $13.5(12.0 \sim 15.0)$ & $15.6(13.8 \sim 17.4)$ & $13.1(11.9 \sim 14.3)$ & $10.4(9.0 \sim 11.8)$ & $2.6(2.0 \sim 3.1)$ \\
\hline \multirow{2}{*}{ 八 $\quad$ 厶 } & $\mathrm{L}$ & $8.0(7.2 \sim 9.0)$ & $11.3(10.4 \sim 12.2)$ & $12.1(11.1 \sim 13.0)$ & $11.8(10.9 \sim 12.8)$ & $10.1(7.9 \sim 12.2)$ & $3: 2(2.5 \sim 3.9)$ \\
\hline & $\mathrm{R}$ & $8.5(7.0 \sim 10.0)$ & $12.7(11.7 \sim 13.8)$ & $13.4(11.8 \sim 14.8)$ & $12.9(12.0 \sim 13.8)$ & $10.3(8.6 \sim 12.0)$ & $3.2(2.6 \sim 3.7)$ \\
\hline \multirow{2}{*}{ タクアン } & $\mathrm{L}$ & $10.1(7.9 \sim 12.2)$ & $13.1(11.3 \sim 15.0)$ & $12.1(10.7 \sim 13.7)$ & $12.7(11.8 \sim 13.7)$ & $10.7(9.9 \sim 11.4)$ & $3.1(2.7 \sim 3.5)$ \\
\hline & $\mathrm{R}$ & $10.3(8.6 \sim 12.0)$ & $12.6(10.6 \sim 13.7)$ & $11.4(9.9 \sim 13.0)$ & $11.3(10.6 \sim 12.2)$ & $10.3(9.2 \sim 11.6)$ & $3.0(2.6 \sim 3.5)$ \\
\hline
\end{tabular}

注：表 3 下注参照

\section{第 3 節 咀嚼力と対合力}

ピーナッツ，ハムおよびタクアンの咀嚼過程における 且嚼力および筋電図を同時記録し, 表 $3 ， 4$ および図 1〜16のような成績を得た. さらに, その咀嚼リズム, おなわち放電持続時間 (D), 間隔 (I), 周期 (T) およ バ放電周期に対する放電持続時間の割合 $(D / T)$ は表 '〜12に示すとおりである.

各種食物咀嚼時の各期における咀啷力は, $30^{\circ}$ 人工白 氛の方が $20^{\circ}$ 人工臼歯より小さい傾向であり，曣下期の 讨合力においてはその逆の傾向が認められたが，ピーナ ッッ咀嚼の $2 \sim 4$ 期の左側および八ム咀緭の 2 期の両側 こおいて，有意に小であった.

各種食物の咀嚼りズム各期についてみると，30ㅅ工 当歯と $20^{\circ}$ 人工歯ともに側差は認められなかった. D うよび $\mathrm{D} / \mathrm{T}$ は $30^{\circ}$ 人工歯の方が小さい傾向を示し， I とTとは $30^{\circ}$ 人工臼歯の方が大きい傾向を示した.

\section{第 4 節 咀嚼カと筋電図}

ピーナッツ，八ムおよぴタクアン咀嚼における各期の 且嚼力の筋電図所見は表 5,6 および図 11〜16 に示すご 上くである. その咀嚼りズム，すなわち放電持続時間
(D), 間隔 (I), 周期 ( $\mathrm{T}$ ) および放電周期に対する放電 持続時間の割合 $(D / T)$ については表 7〜12 に示すごと くである.

各種食物咀嚼時において $30^{\circ}$ 人工鼠歯の活動状態は, $20^{\circ}$ 人工臼歯のそれよりも小さい傾向を示したが, 鱟下 期で差はみられなかった.

各種食物の咀嚼りズムについてみると，ピーナッッ咀 嚼の両人工臼歯は 1 〜 期を通じてほぼ同程度を示した が，臙下期の $30^{\circ}$ 人工臼歯の方が大きい傾向を示した. とくに I と Tの 1 期において $30^{\circ}$ 人工白歯の方が有意に 小であり，讌下期においては有意に大であった。八厶咀 畄の $30^{\circ}$ 人工臼歯は $1 \sim 5$ 期を通じて $20^{\circ}$ 人工臼歯より 小さい傾向を示したが，臙下期においては $30^{\circ}$ 人工臼歯 の方が大きい傾向であった. とくに 5 期における Tの $30^{\circ}$ 人工臼歯の方が有意に小であるが，嚥下期における Tの $30^{\circ}$ 人工臼歯の方は有意に大であった. タクアン勗 嚼の $30^{\circ}$ 人工白蒾は $1 \sim 5$ 期を通じて $20^{\circ}$ 人工臼歯より 小さい傾向を示し，とくに $2 \sim 5$ 期における D, 1 と 4 期におけるTおよび 5 期における D/T において有意に 小であった. 

1 朝
2 細
3 期
4 朝
5 影
下期

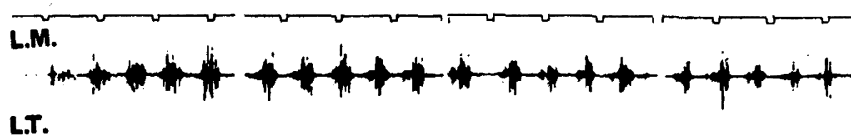

L.T.

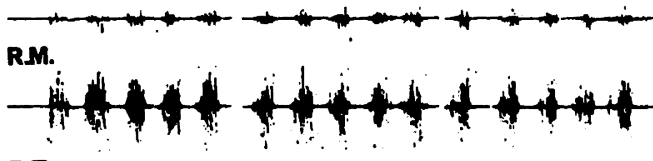

R.T.

LMF.

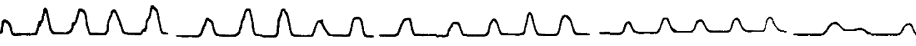

RMF.

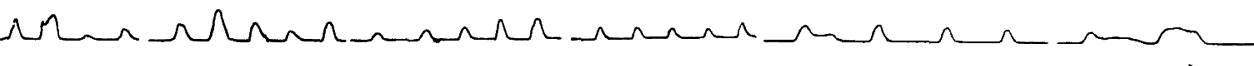

$$
\begin{aligned}
& \text { I sec }
\end{aligned}
$$

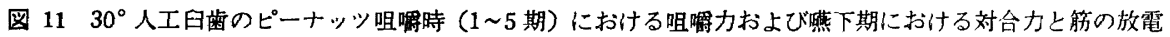
(被験者 : G.T.)

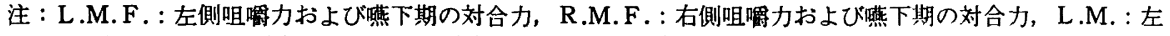
側咬管, L.T. : 左側頭管, R.M. : 右側咬筋, R.T. : 右側頭筋

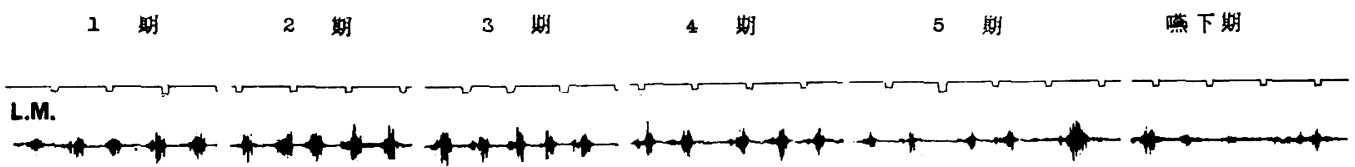

L.T.

RM.

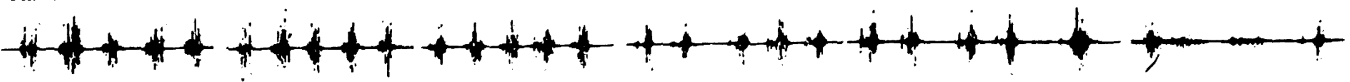

R.T.

LMF:

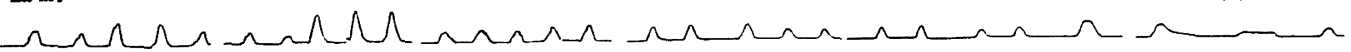

RMF.

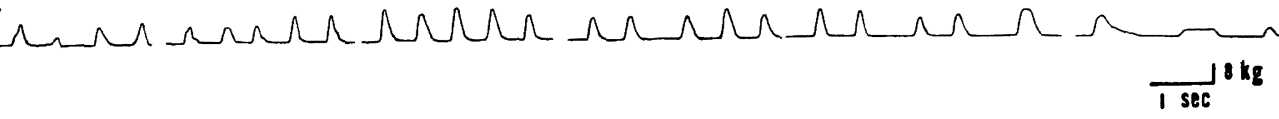

図 $1220^{\circ}$ 人工臼歯のピーナッッ咀絪時（1～5 期）における咀嚼力および鱟下期における対合力と筋の放電 (被験者 : G.T.)

注 : 図 11 下注参照 


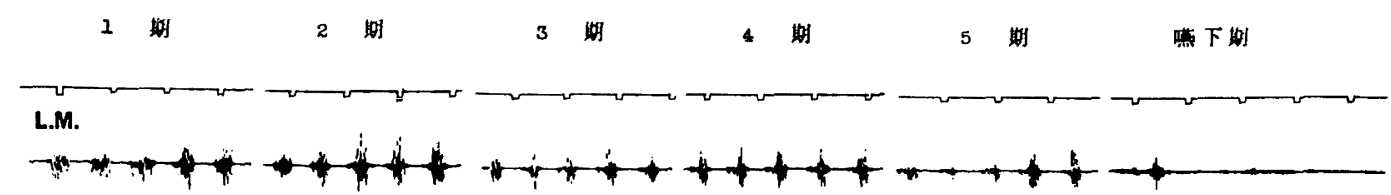

L.T.

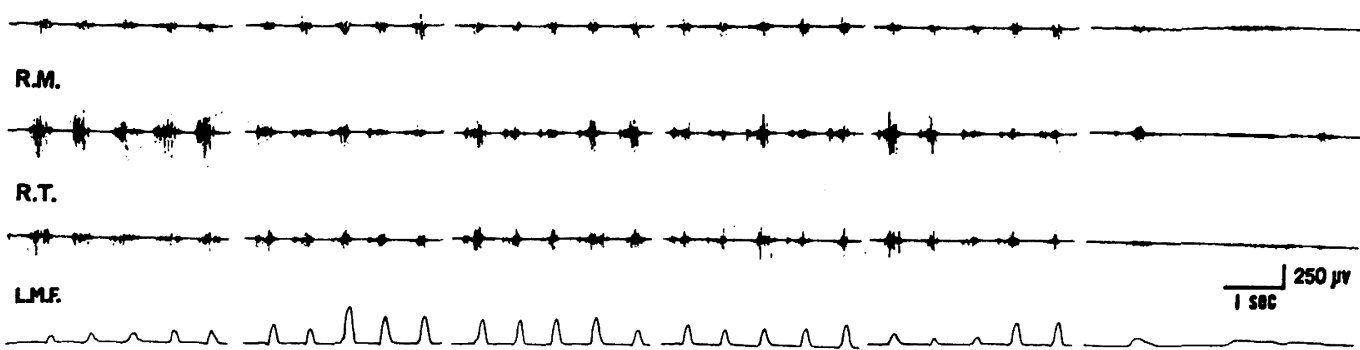

RMYF.

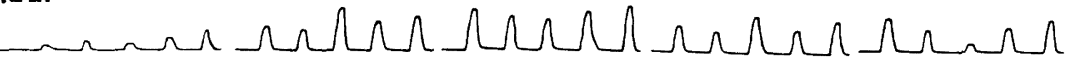

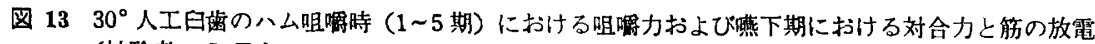
(被験者 : G.T.)

注 : 図 11 下注参照

12 的 2 期 $\quad 3$ 期 $\quad 4$ 期 $\quad 5$ 期

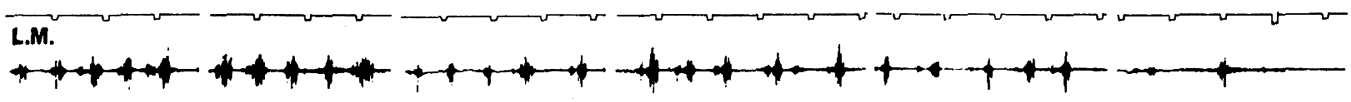

L.T.

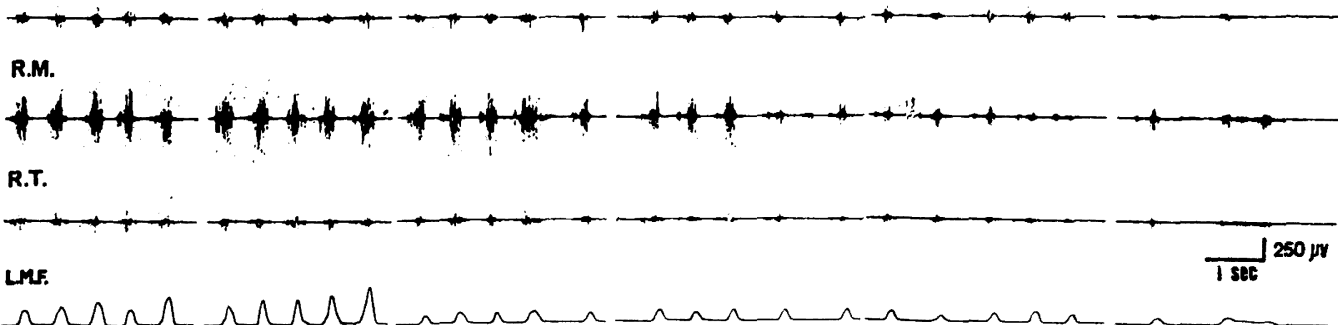

LMF:

RMF.

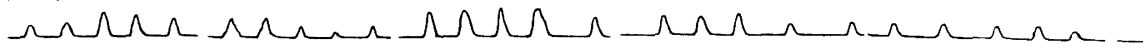

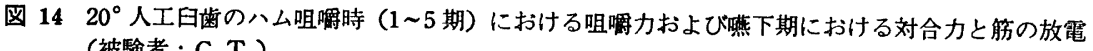
(被験者 : G.T.) 注 : 図 11 下注参照 

1 的
2 녕
3 歇
4 期
5 期
䓵下期

L.M.

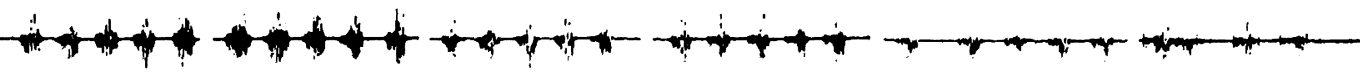
L.T.

RM.

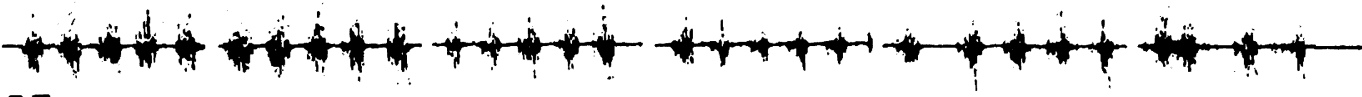
R.T.

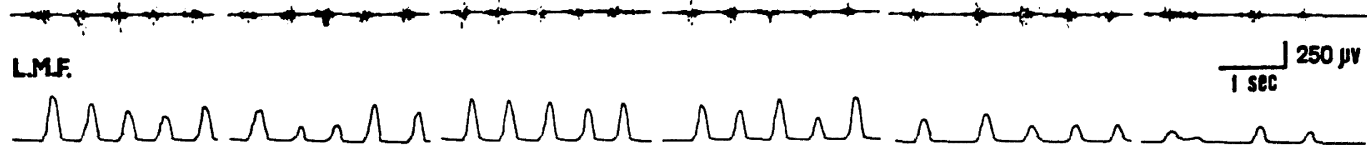
RMF.

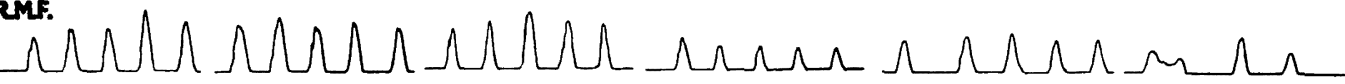
$\int_{\mathrm{ISec}} \mathrm{s} \mathrm{kg}$

図 $1530^{\circ}$ 人工歯のタクアン咀嚼時（1５期）における咀嚼力および蕉下期における対合力と筋の放電（被験者 : G.T.） 注 : 図 11 下注参照
1 期
2 期
3 期
4 期
5 期
䓵下期

L.M.

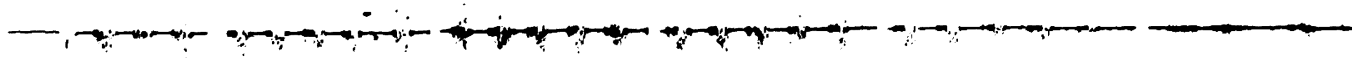

L.T.

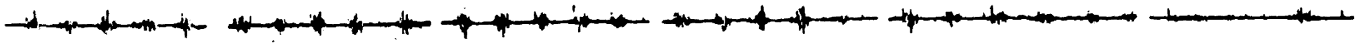

R.M.

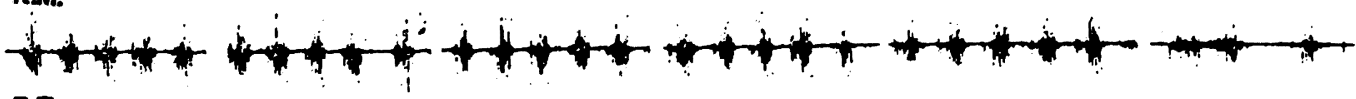
R.T.

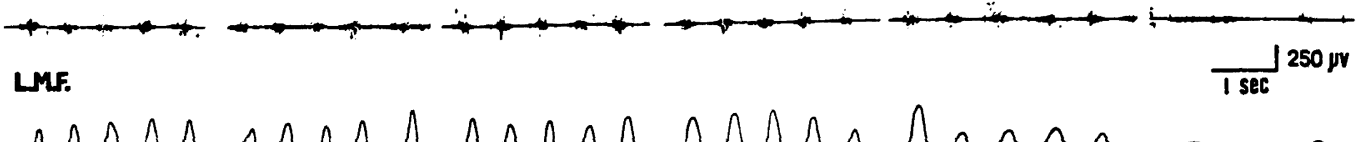

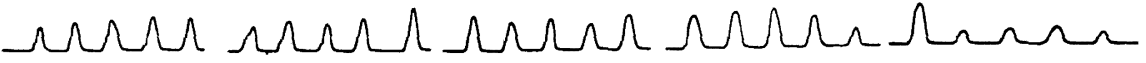

RMF.

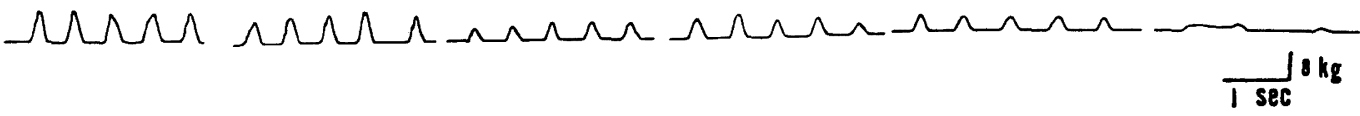

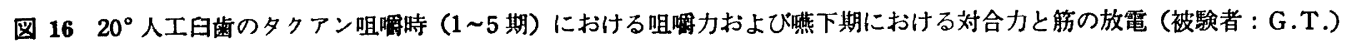
注 : 図 11 下注参照 
表 $530^{\circ}$ 人工甶歯の各食物における各期および 藇下期の筋の放電の程度

\begin{tabular}{|c|c|c|c|c|c|c|c|}
\hline & 体誠 & 1 期 & 2 期 & 3 期 & 4 期 & 5 期 & 嚾下期 \\
\hline \multirow{2}{*}{ ピーナッツ } & $L$ & H & $H$ & $\#$ & \# & $t \sim H$ & + \\
\hline & $\mathrm{R}$ & \# & $t$ & H & \# & $t \sim H$ & + \\
\hline \multirow{2}{*}{ 八 ム } & L & H & H & H & \# & $t \sim H$ & + \\
\hline & $R$ & \# & $H$ & \# & H & $t \sim H$ & + \\
\hline \multirow{2}{*}{ タクアン } & $L$ & H & $\#$ & $\#$ & \# & $t \sim \#$ & + \\
\hline & $\mathrm{R}$ & \# & \# & $\#$ & \# & $t \sim \#$ & + \\
\hline
\end{tabular}

注: $\mathrm{H}$ (強度) $: 200 \mu \mathrm{VWL}$ 等度) $: 200 \mu \mathrm{V} \sim 50 \mu \mathrm{V}$ $+($ 轱度 $): 50 \mu \mathrm{VW下}$
表 $620^{\circ}$ 人工田菌の各食物における各期および 攃下期の筋の放電の程度

\begin{tabular}{|c|c|c|c|c|c|c|c|}
\hline & 体溉 & 1 期 & 2 期 & 3 期 & 4 期 & 5 期 & 烝下期 \\
\hline \multirow{2}{*}{ ピーナッッ } & $\mathrm{L}$ & $H \sim H$ & H & $H \sim H$ & $H \sim H$ & $\#$ & + \\
\hline & $\mathrm{R}$ & $H \sim H$ & $H$ & $H \sim H$ & $H \sim H$ & H & + \\
\hline \multirow{2}{*}{ 八公 } & L & $H \sim H$ & H & $H \sim H$ & $H-\mathbb{H}$ & H & + \\
\hline & $\mathrm{R}$ & $H \sim H$ & $H$ & $H \sim H$ & $H \sim H$ & H & + \\
\hline \multirow{2}{*}{ タクアン } & L & $H \sim H$ & $H$ & $H \sim H$ & $H-H$ & $H$ & + \\
\hline & $\mathrm{R}$ & $H \sim \mathbb{H}$ & $H$ & $H \sim H$ & $H-H$ & H & $t$ \\
\hline
\end{tabular}

注：表5 个注参照

表 $730^{\circ}$ 人工鼠のピーナッッにおける咀毗リズムおよび蕉下パターン

\begin{tabular}{|c|c|c|c|c|c|c|c|}
\hline & & 期 & 期 & 期 & 期 & 期 & 葵 \\
\hline \multirow{4}{*}{ L. M. } & D & $0.41(0.40 \sim 0.43)$ & $0.40(0.39 \sim 0.41)$ & $0.39(0.38 \sim 0.40)$ & $0.39(0.37 \sim 0.41)$ & $0.46(0.43 \sim 0.49)$ & $0.82(0.69 \sim 0.94)$ \\
\hline & I & $0.29(0.27 \sim 0.31)$ & $0.31(0.29 \sim 0.33)$ & $0.33(0.31 \sim 0.35)$ & $0.35(0.33 \sim 0.37)$ & $0.46(0.42 \sim 0.51)$ & $0.78(0.64 \sim 0.91)$ \\
\hline & $\mathrm{T}$ & $0.70(0.68-0.72)$ & $0.71(0.69 \sim 0.73)$ & $0.72(0.70 \sim 0.74)$ & $0.74(0.72 \sim 0.76)$ & $0.93(0.87 \sim 0.99)$ & $1.59(1.37 \sim 1.82)$ \\
\hline & $\mathrm{D} / \mathrm{T}$ & $0.59(0.57 \sim 0.61)$ & $0.56(0.54 \sim 0.58)$ & $0.55(0.53 \sim 0.57)$ & $0.52(0.50 \sim 0.54)$ & $0.50(0.47 \sim 0.52)$ & $0.52(0.49 \sim 0.56)$ \\
\hline \multirow{4}{*}{ L. T. } & D & $0.37(0.35 \sim 0.39)$ & $0.35(0.33 \sim 0.38)$ & $0.35(0.33-0.37)$ & $0.34(0.32 \sim 0.36)$ & $0.38(0.35 \sim 0.40)$ & $0.72(0.60 \sim 0.84)$ \\
\hline & I & $0.32(0.30 \sim 0.34)$ & $0.36(0.34 \sim 0.38)$ & $0.37(0.35 \sim 0.39)$ & $0.41(0.39 \sim 0.43)$ & $0.56(0.51 \sim 0.61)$ & $0.83(0.66 \sim 1.01)$ \\
\hline & $\mathrm{T}$ & $0.69(0.67 \sim 0.71)$ & $0.70(0.68 \sim 0.72)$ & $0.72(0.70 \sim 0.74)$ & $0.74(0.72 \sim 0.76)$ & $0.94(0.88 \sim 1.00)$ & $1.55(1.31 \sim 1.98)$ \\
\hline & $\mathrm{D} / \mathrm{T}$ & $0.54(0.52 \sim 0.56)$ & $0.50(0.48 \sim 0.52)$ & $0.49(0.47 \sim 0.51)$ & $0.45(0.43 \sim 0.47)$ & $0.41(0.39 \sim 0.43)$ & $0.46(0.41 \sim 0.51)$ \\
\hline \multirow{4}{*}{ R. M. } & D & $0.42(0.40 \sim 0.44)$ & $0.40(0.38 \sim 0.42)$ & $0.40(0.38 \sim 0.42)$ & $0.42(0.40 \sim 0.44)$ & $0.49(0.45 \sim 0.51)$ & $0.77(0.66 \sim 0.88)$ \\
\hline & 1 & $0.28(0.26 \sim 0.30)$ & $0.31(0.29-0.33)$ & $0.32(0.30 \sim 0.34)$ & $0.33(0.31 \sim 0.35)$ & $0.46(0.42 \sim 0.51)$ & $0.74(0.60 \sim 0.88)$ \\
\hline & $T$ & $0.70(0.68 \sim 0.72)$ & $0.71(0.69 \sim 0.73)$ & $0.72(0.70 \sim 0.74)$ & $0.75(0.73 \sim 0.77)$ & $0.94(0.88 \sim 1.01)$ & $1.51(1.30 \sim 1.73)$ \\
\hline & $\mathrm{D} / \mathrm{T}$ & $0.60(0.58 \sim 0.62)$ & $0.56(0.54 \sim 0.58)$ & $0.56(0.54 \sim 0.58)$ & $0.57(0.55 \sim 0.59)$ & $0.52(0.49 \sim 0.54)$ & $0.52(0.48 \sim 0.57)$ \\
\hline \multirow{4}{*}{ R. T. } & D & $0.40(0.38 \sim 0.42)$ & $0.38(0.36 \sim 0.40)$ & $0.37(0.35 \sim 0.39)$ & $0.37(0.35 \sim 0.39)$ & $0.38(0.35 \sim 0.41)$ & $0.73(0.61 \sim 0.85)$ \\
\hline & I & $0.29(0.27 \sim 0.31)$ & $0.34(0.32 \sim 0.36)$ & $0.35(0.33 \sim 0.37)$ & $0.37(0.35 \sim 0.39)$ & $0.54(0.49 \sim 0.59)$ & $0.86(0.70 \sim 1.02)$ \\
\hline & $\mathrm{T}$ & $0.68(0.66 \sim 0.70)$ & $0.72(0.70 \sim 0.74)$ & $0.72(0.70 \sim 0.74)$ & $0.75(0.73 \sim 0.77)$ & $0.93(0.88 \sim 0.99)$ & $1.59(1.37 \sim 1.81)$ \\
\hline & $\mathrm{D} / \mathrm{T}$ & $0.58(0.56 \sim 0.60)$ & $0.53(0.51 \sim 0.55)$ & $0.52(0.50 \sim 0.54)$ & $0.50(0.48 \sim 0.52)$ & $0.44(0.41 \sim 0.47)$ & $0.47(0.43 \sim 0.52)$ \\
\hline \multirow{4}{*}{ L. M.F. } & D & $0.34(0.32 \sim 0.36)$ & $0.27(0.25 \sim 0.29)$ & $0.25(0.23 \sim 0.27)$ & $0.27(0.25 \sim 0.29)$ & $0.31(0.28 \sim 0.34)$ & $0.56(0.42 \sim 0.69)$ \\
\hline & I & $0.35(0.33 \sim 0.37)$ & $0.44(0.42 \sim 0.46)$ & $0.48(0.46 \sim 0.50)$ & $0.48(0.46 \sim 0.50)$ & $0.66(0.60 \sim 0.73)$ & $1.04(0.82 \sim 1.25)$ \\
\hline & $\mathrm{T}$ & $0.70(0.68 \sim 0.72)$ & $0.71(0.69 \sim 0.73)$ & $0.73(0.71 \sim 0.75)$ & $0.75(0.73 \sim 0.77)$ & $0.97(0.90 \sim 1.05)$ & $1.59(1.29 \sim 1.89)$ \\
\hline & $\mathrm{D} / \mathrm{T}$ & $0.49(0.47 \sim 0.51)$ & $0.38(0.36 \sim 0.40)$ & $0.35(0.33 \sim 0.37)$ & $0.36(0.34 \sim 0.38)$ & $0.33(0.31 \sim 0.35)$ & $0.36(0.30 \sim 0.41)$ \\
\hline \multirow{4}{*}{ R.M.F. } & D & $0.32(0.30 \sim 0.34)$ & $0.30(0.28 \sim 0.32)$ & $0.28(0.27 \sim 0.29)$ & $0.28(0.27 \sim 0.29)$ & $0.30(0.28 \sim 0.32)$ & $0.57(0.44 \sim 0.70)$ \\
\hline & I & $0.38(0.36 \sim 0.40)$ & $0.41(0.39 \sim 0.43)$ & $0.45(0.43 \sim 0.47)$ & $0.47(0.45 \sim 0.49)$ & $0.68(0.61 \sim 0.75)$ & $1.11(0.88 \sim 1.34)$ \\
\hline & $\mathrm{T}$ & $0.70(0.68 \sim 0.72)$ & $0.71(0.69 \sim 0.73)$ & $0.73(0.71 \sim 0.75)$ & $0.75(0.73 \sim 0.77)$ & $0.98(0.90 \sim 1.06)$ & $1.68(1.37 \sim 1.99)$ \\
\hline & $\mathrm{D} / \mathrm{T}$ & $0.46(0.44 \sim 0.48)$ & $0.43(0.40 \sim 0.46)$ & $0.39(0.37 \sim 0.41)$ & $0.37(0.35 \sim 0.39)$ & $0.32(0.30 \sim 0.34)$ & $0.35(0.30 \sim 0.40)$ \\
\hline
\end{tabular}

注：L.M.：左側咬荕 L.M.F.：左咀嘬力

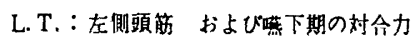

R.M.：右㑡咬筋 R.M.F.：右側咀噃力

R.T.：右側頭筋 およU㗪下期の对台力
$\mathrm{D}$ ：故電持続時間 $(\mathrm{sec}$.

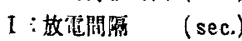

$\mathrm{T}:$ 故䇴周期 (sec.)

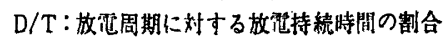

（）内は $\alpha=0.05 に お け る$ 信槙区開 
表 $820^{\circ}$ 人工臼歯のピーナッツにおける咀嚼りズムおよび㵊下パターン

\begin{tabular}{|c|c|c|c|c|c|c|c|}
\hline & & 期 & 期 & 期 & 期 & 期 & 䓵 下 \\
\hline \multirow{4}{*}{ L. M. } & $\mathrm{D}$ & $0.39(0.37 \sim 0.41)$ & $0.38(0.36 \sim 0.41)$ & $0.39(0.36 \sim 0.41)$ & $0.40(0.37 \sim 0.43)$ & $0.42(0.39 \sim 0.46)$ & $0.51(0.43 \sim 0.58)$ \\
\hline & 1 & $0.39(0.37 \sim 0.41)$ & $0.37 \div 0.34 \sim 0.40$ & $0.36(0.33 \sim 0.39)$ & $0.38(0.35 \sim 0.41)$ & $0.45(0.40 \sim 0.50)$ & $0.48(0.39 \sim 0.58)$ \\
\hline & $\mathrm{T}$ & $0.78(0.75 \sim 0.81)$ & $0.750 .70-0.79$ & $0.75(0.69 \sim 0.78)$ & $0.78(0.74 \sim 0.82)$ & $0.87(0.81 \sim 0.94)$ & $0.99(0.85 \sim 1.13)$ \\
\hline & $\mathrm{D}: \mathrm{T}$ & $0.49(0.47 \sim 0.51)$ & $0.51(0.50 \sim 0.53)$ & $0.53(0.50 \sim 0.55)$ & $0.51(0.49 \sim 0.54)$ & $0.48(0.46 \sim 0.51)$ & $0.52(0.48 \sim 0.57)$ \\
\hline \multirow{4}{*}{ L. T. } & $\mathrm{D}$ & $0.40(0.37 \sim 0.43)$ & $(1.39 \cdot 0.37 \sim 0.41)$ & $0.37: 0.34 \sim 0.40$ & $0.38(0.35 \sim 0.41)$ & $0.40(0.37 \sim 0.44)$ & $0.52(0.43 \sim 0.62)$ \\
\hline & I & $0.38: 0.35 \sim 0.41)$ & $0.3 \div 0.35 \sim 0.39)$ & $0.38(0.35 \sim 0.40)$ & $0.40(0.37 \sim 0.43)$ & $0.46(0.41 \sim 0.52)$ & $0.48(0.39 \sim 0.56)$ \\
\hline & $\mathrm{T}$ & $0.77(0.72 \sim 0.80$ & $0.76: 0.72-0.80)$ & $0.75(0.71 \sim 0.78)$ & $0.78(0.74 \sim 0.82)$ & $0.87(0.77 \sim 0.97)$ & $1.00(0.87 \sim 1.12)$ \\
\hline & $\mathrm{D} / \mathrm{T}$ & $0.51(0.48 \sim 0.53)$ & $0.52: 0.49-0.54$ & $0.50(0.48 \sim 0.53)$ & $0.49(0.47 \sim 0.51)$ & $0.46(0.44 \sim 0.49)$ & $0.52(0.47 \sim 0.57)$ \\
\hline \multirow{4}{*}{ R. M. } & $\mathrm{D}$ & $0.41(0.38 \sim 0.45$ & $0.400 .38-0.42$ & $0.40(0.37 \sim 0.43)$ & $0.41(0.38 \sim 0.44)$ & $0.42(0.38 \sim 0.46)$ & $0.51(0.43 \sim 0.59)$ \\
\hline & I & $0.38(0.35 \sim 0.41)$ & $0.36: 0.33 \sim 0.39$ & $0.35(0.33 \sim 0.38)$ & $0.39(0.36 \sim 0.42)$ & $0.45(0.40 \sim 0.50)$ & $0.49(0.39 \sim 0.58)$ \\
\hline & $\mathrm{T}$ & $0.79(0.76 \sim 0.83$ & $0.76(0.72 \sim 0.80)$ & $0.76(0.72 \sim 0.79)$ & $0.80(0.75 \sim 0.84)$ & $0.87(0.81 \sim 0.94)$ & $1.00(0.86 \sim 1.13)$ \\
\hline & $\mathrm{D} / \mathrm{T}$ & $0.52(0.50 \sim 0.54$ & $0.53(0.51 \sim 0.55)$ & $0.53(0.51 \sim 0.56)$ & $0.51(0.49 \sim 0.54)$ & $0.48(0.44 \sim 0.52)$ & $0.51(0.48 \sim 0.54)$ \\
\hline \multirow{4}{*}{ R. T. } & $\mathrm{D}$ & $0.37(0.35 \sim 1) .40)$ & $0.37(0.35-0.39$ & $0.37(0.35 \sim 0.39)$ & $0.41(0.38 \sim 0.44)$ & $0.42(0.37 \sim 0.46)$ & $0.48(0.40 \sim 0.56)$ \\
\hline & I & $0.41(0.38 \sim 0.44)$ & $0.39(0.35 \sim 0.44)$ & $0.38(0.35 \sim 0.42)$ & $0.45(0.41 \sim 0.49)$ & $0.43(0.38 \sim 0.49)$ & $0.46(0.36 \sim 0.56)$ \\
\hline & $\mathrm{T}$ & $0.78(0.74 \sim 0.83)$ & $0.76(0.72-0) .80$ & $0.75(0.72 \sim 0.78)$ & $0.86(0.82 \sim 0.90)$ & $0.85(0.78 \sim 0.91)$ & $0.95(0.82 \sim 1.09)$ \\
\hline & $\mathrm{D} / \mathrm{T}$ & $0.47(0.44 \sim 0.49)$ & $0.49(0.46 \sim 0.52)$ & $0.50(0.48 \sim 0.53)$ & $0.48(0.45 \sim 0.50)$ & $0.50(0.46 \sim 0.53)$ & $0.52(0.47 \sim 0.57)$ \\
\hline \multirow{4}{*}{ L.M.F. } & $\mathrm{D}$ & $0.34(0.29 \sim 0.39)$ & $0.34(0.31 \sim 0.36)$ & $0.33(0.29 \sim 0.38)$ & $0.28(0.24 \sim 0.31)$ & $0.26(0.21 \sim 0.31)$ & $0.46(0.38 \sim 0.54)$ \\
\hline & I & $0.41(0.37 \sim 0.45$ & $0.42 \div 0.35 \sim 0.48$ & $0.38(0.32 \sim 0.44)$ & $0.38(0.34-0.42)$ & $0.37(0.32 \sim 0.42)$ & $0.43(0.34 \sim 0.52)$ \\
\hline & $\mathrm{T}$ & $0.75(0.69 \sim 0.81)$ & $0.75(0.69 \sim 0.81)$ & $0.71(0.65 \sim 0.78)$ & $0.66(0.60 \sim 0.72)$ & $0.61(0.54 \sim 0.68)$ & $0.89(0.75 \sim 1.03)$ \\
\hline & $\mathrm{D} / \mathrm{T}$ & $0.45(0.40 \sim 0.49)$ & $0.46(0.41 \sim 0.50)$ & $0.46(0.41 \sim 0.50)$ & $0.42(0.39 \sim 0.45)$ & $0.43(0.37 \sim 0.49)$ & $0.52(0.48 \sim 0.56)$ \\
\hline \multirow{4}{*}{ R.M.F. } & $\mathrm{D}$ & $0.34(0.29 \sim 0.38$ & $0.31(0.28 \sim 0.34)$ & $0.33(0.28 \sim 0.38)$ & $0.33(0.29 \sim 0.37)$ & $0.32(0.27 \sim 0.37)$ & $0.45(0.37 \sim 0.53)$ \\
\hline & I & $0.38(0.33 \sim 0.43)$ & $0.45(0.40 \sim 0.50)$ & $0.42(0.37 \sim 0.48)$ & $0.40(0.35 \sim 0.44)$ & $0.37(0.32 \sim 0.42)$ & $0.41(0.32 \sim 0.50)$ \\
\hline & $\mathrm{T}$ & $0.71(0.64 \sim 0.79)$ & $0.76(0.70 \sim 0.82)$ & $0.75(0.69 \sim 0.82)$ & $0.73(0.66 \sim 0.80)$ & $0.69(0.62 \sim 0.76)$ & $0.86(0.72 \sim 1.00)$ \\
\hline & $\mathrm{D} / \mathrm{T}$ & $0.47(0.43 \sim 0.51)$ & $0.41(0.37 \sim 0.45)$ & $0.44(0.39 \sim 0.49)$ & $0.45(0.42 \sim 0.49)$ & $0.46(0.40 \sim 0.52)$ & $0.52(0.48 \sim 0.56)$ \\
\hline
\end{tabular}

注：表 7 下注参照

\section{第 4 章 総括および検討}

$30^{\circ}$ および $20^{\circ}$ 人工臼歯の総義菊における咬合力, 咀 緭力および筋電図の成績を総括し, 検討すると次のとお りである。

1. 各下瀕位における咬合力およびその活動開始時間 の側差は，表 1 および 2 に示すと㧍りである.

総義歯の咬合力に関しては, 上下人工臼歯間に咬合力 測定装置を介在させて行う方法 ${ }^{25,33,34)}$ ，人工田歯内に 咬合力測定装置を埋入して行う方法で測定し $27 \sim 30,35,36)$, それぞれ報告されている，そこで，著者の成績と著者が 準した深水など27 30) と比較してみると，咬頭嵌合位で $0.2 \mathrm{~kg}$, 側方咬合位では作業側で $0.1 \mathrm{~kg}$, 平衡側で 0.3 $\mathrm{kg}$ および前方咬合位で $0.6 \mathrm{~kg}$ それぞれ小である.

従来, 咬合力と人工臼歯の咬合面形態との関連につい ての研究は, 人工歯の大きさ, 形態などの制約に合った 咬合力測定装置が開発できず，人工田歯の咬合面形態の 相違による咬合力に関する研究は久松 ${ }^{30}$ 以外, 著者の知 る限りにおいてみられない，著者の両人工四歯の交換方 法抒よび咬合調整法は久松 ${ }^{30)}$ に準じているので， $30^{\circ}$ 人 工刍歯と $20^{\circ}$ 人工白歯の総義歯の第 1 大臼歯の咬合面形 態㧍よび咬頭傾斜の相違による咬合力値が得られる. そ の結果, 咬頭嵌合位と前方咬合位に扔ける $30^{\circ}$ 人工臼歯 の咬合力は $20^{\circ}$ 人工王歯より大きい傾向が認められる. その差は解剖学的人工臼歯として $30^{\circ}$ 人工田歯と半解剖 学的人工歯として $20^{\circ}$ 人工臼歯をもちいたため, その 咬合面の咬頭, 溝および隆線の走行などの形態的な相違 
表 $930^{\circ}$ 人工臼歯の八厶におけける咀嚼リズムおよび爑下パターン

\begin{tabular}{|c|c|c|c|c|c|c|c|}
\hline & & 期 & 期 & 期 & 期 & 期 & 热 \\
\hline \multirow{4}{*}{ L. M. } & $\mathrm{D}$ & $0.40(0.38 \sim 0.42)$ & $0.37(0.36 \sim 0.39)$ & $0.36(0.34 \sim 0.38)$ & $0.35(0.34 \sim 0.37)$ & $0.37(0.35 \sim 0.40)$ & $0.70(0.55 \sim 0.84)$ \\
\hline & I & $0.34(0.33 \sim 0.36)$ & $0.35(0.33 \sim 0.37)$ & $0.36(0.35 \sim 0.38)$ & $0.37(0.35 \sim 0.39)$ & $0.42(0.39 \sim 0.45)$ & $0.64(0.42 \sim 0.85)$ \\
\hline & $\mathrm{T}$ & $0.74(0.71 \sim 0.76)$ & $0.73(0.71 \sim 0.75)$ & $0.72(0.70 \sim 0.75)$ & $0.72(0.70 \sim 0.75)$ & $0.79(0.75 \sim 0.83)$ & $1.33(1.07 \sim 1.59)$ \\
\hline & $\mathrm{D} / \mathrm{T}$ & $0.54(0.52 \sim 0.56)$ & $0.50(0.48 \sim 0.52)$ & $0.50(0.48 \sim 0.52)$ & $0.49(0.47 \sim 0.51)$ & $0.47(0.45 \sim 0.50)$ & $0.52(0.45 \sim 0.58)$ \\
\hline \multirow{4}{*}{ L. T. } & $\mathrm{D}$ & $0.41(0.39 \sim 0.43)$ & $0.36(0.34 \sim 0.38)$ & $0.34(0.33 \sim 0.36)$ & $0.32(0.30 \sim 0.34)$ & $0.35(0.32 \sim 0.37)$ & $0.70(0.56 \sim 0.84)$ \\
\hline & I & $0.34(0.32 \sim 0.35)$ & $0.37(0.35 \sim 0.40)$ & $0.39(0.36 \sim 0.41)$ & $0.40(0.38 \sim 0.42)$ & $0.43(0.40 \sim 0.47)$ & $0.69(0.47 \sim 0.91)$ \\
\hline & $\mathrm{T}$ & $0.75(0.73 \sim 0.77)$ & $0.73(0.71 \sim 0.76)$ & $0.73(0.71 \sim 0.76)$ & $0.73(0.71 \sim 0.75)$ & $0.78(0.72 \sim 0.82)$ & $1.39(1.13 \sim 1.65)$ \\
\hline & $\mathrm{D} / \mathrm{T}$ & $0.55(0.53-0.57)$ & $0.50(0.47 \sim 0.52)$ & $0.47(0.45 \sim 0.49)$ & $0.45(0.43 \sim 0.48)$ & $0.45(0.43 \sim 0.48)$ & $0.51(0.45 \sim 0.57)$ \\
\hline \multirow{4}{*}{ R. M. } & $\mathrm{D}$ & $0.43(0.41 \sim 0.45)$ & $0.40(0.38 \sim 0.42)$ & $0.38(0.37 \sim 0.40)$ & $0.40(0.38 \sim 0.41)$ & $0.39(0.37 \sim 0.42)$ & $0.71(0.57 \sim 0.85)$ \\
\hline & I & $0.32(0.31 \sim 0.34)$ & $0.33(0.31 \sim 0.35)$ & $0.34(0.32 \sim 0.35)$ & $0.35(0.33 \sim 0.37)$ & $0.41(0.38 \sim 0.44)$ & $0.61(0.39-0.84)$ \\
\hline & $\mathrm{T}$ & $0.75(0.72 \sim 0.77)$ & $0.73(0.71 \sim 0.75)$ & $0.72(0.70 \sim 0.74)$ & $0.74(0.72 \sim 0.76)$ & $0.79(0.75 \sim 0.84)$ & $1.32(1.05 \sim 1.59)$ \\
\hline & $\mathrm{D} / \mathrm{T}$ & $0.57(0.55 \sim 0.59)$ & $0.55(0.53 \sim 0.57)$ & $0.53(0.51 \sim 0.54)$ & $0.53(0.51 \sim 0.55)$ & $0.50(0.48 \sim 0.52)$ & $0.58(0.52 \sim 0.64)$ \\
\hline \multirow{4}{*}{ R. T. } & $\mathrm{D}$ & $0.41(0.39 \sim 0.43)$ & $0.38(0.36 \sim 0.40)$ & $0.38(0.36 \sim 0.39)$ & $0.33(0.32 \sim 0.35)$ & $0.35(0.33 \sim 0.37)$ & $0.66(0.52-0.80)$ \\
\hline & $I$ & $0.34(0.32-0.36)$ & $0.36(0.33 \sim 0.38)$ & $0.36(0.34 \sim 0.39)$ & $0.40(0.38 \sim 0.42)$ & $0.44(0.40 \sim 0.47)$ & $0.67(0.45 \sim 0.89)$ \\
\hline & $\mathrm{T}$ & $0.75(0.71 \sim 0.78)$ & $0.73(0 . \pi \sim 0.76)$ & $0.73(0.70 \sim 0.75)$ & $0.73(0.70 \sim 0.75)$ & $0.79(0.75 \sim 0.83)$ & $1.32(1.07-1.57)$ \\
\hline & $\mathrm{D} / \mathrm{T}$ & $0.55(0.53 \sim 0.57)$ & $0.52(0.50 \sim 0.54)$ & $0.50(0.47 \sim 0.52)$ & $0.46(0.44 \sim 0.48)$ & $0.46(0.43 \sim 0.48)$ & $0.50(0.43 \sim 0.57)$ \\
\hline \multirow{4}{*}{ L.M.F. } & $\mathrm{D}$ & $0.31(0.28 \sim 0.33)$ & $0.29(0.28 \sim 0.30)$ & $0.27(0.26 \sim 0.29)$ & $0.28(0.27 \sim 0.30)$ & $0.26(0.24 \sim 0.27)$ & $0.58(0.44 \sim 0.71)$ \\
\hline & I & $0.44(0.40 \sim 0.49)$ & $0.42(0.40 \sim 0.44)$ & $0.46(0.43 \sim 0.48)$ & $0.44(0.41 \sim 0.48)$ & $0.55(0.51 \sim 0.60)$ & $0.84(0.70 \sim 0.98)$ \\
\hline & $\mathrm{T}$ & $0.75(0.70-0.79)$ & $0.71(0.67 \sim 0.74)$ & $0.73(0.70 \sim 0.76)$ & $0.72(0.68 \sim 0.75)$ & $0.81(0.76 \sim 0.86)$ & $1.42(1.07 \sim 1.76)$ \\
\hline & $\mathrm{D} / \mathrm{T}$ & $0.41(0.38 \sim 0.44)$ & $0.41(0.39 \sim 0.42)$ & $0.38(0.36 \sim 0.39)$ & $0.39(0.36 \sim 0.41)$ & $0.33(0.31 \sim 0.34)$ & $0.41(0.33 \sim 0.48)$ \\
\hline \multirow{4}{*}{ R.M. F. } & $\mathrm{D}$ & $0.30(0.28 \sim 0.32)$ & $0.30(0.28 \sim 0.31)$ & $0.29(0.28 \sim 0.31)$ & $0.29(0.27 \sim 0.30)$ & $0.28(0.27 \sim 0.30)$ & $0.68(0.55 \sim 0.60)$ \\
\hline & I & $0.42(0.40 \sim 0.45)$ & $0.43(0.40 \sim 0.46)$ & $0.44(0.42 \sim 0.47)$ & $0.44(0.42 \sim 0.46)$ & $0.54(0.50 \sim 0.59)$ & $0.68(0.53 \sim 0.82)$ \\
\hline & $\mathrm{T}$ & $0.72(0.69 \sim 0.75)$ & $0.73(0.70 \sim 0.76)$ & $0.74(0.71 \sim 0.76)$ & $0.73(0.70 \sim 0.75)$ & $0.82(0.78 \sim 0.87)$ & $1.36(1.15 \sim 1.57)$ \\
\hline & $\mathrm{D} / \mathrm{T}$ & $0.42(0.39 \sim 0.44)$ & $0.41(0.39 \sim 0.43)$ & $0.40(0.38 \sim 0.42)$ & $0.40(0.38 \sim 0.42)$ & $0.36(0.33 \sim 0.38)$ & $0.50(0.43 \sim 0.57)$ \\
\hline
\end{tabular}

注：表 7 下注参照

によるものと考えられる．また，両人工臼歯とも咬頭嵌 合位と前方咬合位において側差に有意でなく, 総義歯の 維持安定が保持され，義歯床の動摇，転覆などによって 咀嚼を障害するとは考えられない。

側方咬合位における咬合力は $30^{\circ}$ 人工留の方が $20^{\circ}$ 人工臼歯より大きく，作業側において有意である.この ことは, 両人工臼歯間の咬合面形態の相違が咬合平衡の 付与に差を生じたためと考えられる.

側方滑走運動を肯定している報告37 40)を参考にする と，咀嚼機能に重要な役割を果たすのは側方滑走運動と 考えられ，両側性の咬合平衡を総義歯に付与すること は, 総義歯の維持安定を良好とし，䪽関節を含めた口膑 咀嚼系の機能などが円滑に，能率よく発揮されると考え られる. その意味では $30^{\circ}$ 人工臼蒾および $20^{\circ}$ 人工臼歯
ともそれぞれに側方咬合位での平衡のとりうる人工臼歯 であると考えられる。

咬合力の活動開始時間の側差についてみると，咬頭嵌 合位は咬合力の活動開始時間に側差がなく，前方咬合位 は右側が早、傾向を認め，側方咬合位は作業側の方が有 意に早かった。これは，咬頭嵌合位においては左右が同 時に咬合接触し，総義菌が安定していることを示してい る.さらに，側方咬合位においては作業側が 0.06 0.08 sec. 早く咬合接触するが，とくに総義歯装着者への臨床 診查において，総義歯の維持安定を障害するような要素 とならないことがわかった。

2. 各下滪位における筋の放電状態, 左右の咬筋と側 頭筋の放電開始時間の差および左右の上顥第 1 大臼歯部 の咬合力の開始時間と上述の 4 筋における開始時閒との 
表 $1020^{\circ}$ 人工臼歯のハムにおける咀獣リズムおよび與下パターン

\begin{tabular}{|c|c|c|c|c|c|c|c|}
\hline & & 斯 & 期 & 斯 & 期 & 期 & 茲 \\
\hline \multirow{4}{*}{ L. M. } & D & $0.44(0.41 \sim 0.46)$ & $0.39(0.37 \sim 0.41)$ & $0.38(0.36 \sim 0.39)$ & $0.40(0.38 \sim 0.43)$ & $0.43(0.40 \sim 0.46)$ & $0.53(0.44-0.63)$ \\
\hline & $I$ & $0.40(0.38 \sim 0.43)$ & $0.35(0.33 \sim 0.37)$ & $0.33(0.32 \sim 0.35)$ & $0.33(0.32 \sim 0.35)$ & $0.34(0.31 \sim 0.38)$ & $0.35(0.29-0.42)$ \\
\hline & $T$ & $0.83(0.80 \sim 0.87)$ & $0.74(0.73 \sim 0.76)$ & $0.71(0.69 \sim 0.73)$ & $0.73(0.70 \sim 0.76)$ & $0.77(0.73 \sim 0.82)$ & $0.88(0.76 \sim 1.01)$ \\
\hline & $\mathrm{D} / \mathrm{T}$ & $0.52(0.50 \sim 0.54)$ & $0.53(0.51 \sim 0.56)$ & $0.53(0.51 \sim 0.55)$ & $0.54(0.53 \sim 0.56)$ & $0.56(0.53 \sim 0.58)$ & $0.60(0.55 \sim 0.65)$ \\
\hline \multirow{4}{*}{ L. T. } & D & $0.45(0.42 \sim 0.48)$ & $0.40(0.37 \sim 0.42)$ & $0.38(0.36 \sim 0.40)$ & $0.39(0.37 \sim 0.41)$ & $0.41(0.38 \sim 0.44)$ & $0.52(0.41 \sim 0.63)$ \\
\hline & I & $0.36(0.33 \sim 0.39)$ & $0.33(0.31 \sim 0.35)$ & $0.33(0.32 \sim 0.35)$ & $0.35(0.33 \sim 0.37)$ & $0.36(0.34 \sim 0.38)$ & $0.36(0.31-0.42)$ \\
\hline & $\mathrm{T}$ & $0.82(0.78 \sim 0.86)$ & $0.74(0.72-0.75)$ & $0.71(0.69 \sim 0.73)$ & $0.74(0.70 \sim 0.77)$ & $0.78(0.74 \sim 0.81)$ & $0.88(0.80-0.96)$ \\
\hline & $\mathrm{D} / \mathrm{T}$ & $0.55(0.53 \sim 0.57)$ & $0.55(0.53 \sim 0.57)$ & $0.53(0.51 \sim 0.55)$ & $0.53(0.51 \sim 0.55)$ & $0.53(0.50 \sim 0.55)$ & $0.59(0.55-0.63)$ \\
\hline \multirow{4}{*}{ R. M. } & D & $0.45(0.43 \sim 0.48)$ & $0.41(0.39 \sim 0.42)$ & $0.40(0.38 \sim 0.41)$ & $0.40(0.38 \sim 0.42)$ & $0.45(0.41 \sim 0.49)$ & $0.53(0.44-0.63)$ \\
\hline & I & $0.40(0.37-0.44)$ & $0.33(0.31 \sim 0.35)$ & $0.32(0.30 \sim 0.33)$ & $0.34(0.32 \sim 0.36)$ & $0.33(0.31 \sim 0.36)$ & $0.41(0.34-0.47)$ \\
\hline & $\mathrm{T}$ & $0.84(0.81 \sim 0.87$ & $0.74(0.72 \sim 0.75)$ & $0.72(0.70 \sim 0.73)$ & $0.74(0.71 \sim 0.77)$ & $0.78(0.75 \sim 0.82)$ & $0.94(0.82-1.06)$ \\
\hline & $\mathrm{D} / \mathrm{T}$ & $0.54(0.51 \sim 0.57)$ & $0.55(0.53 \sim 0.5 i)$ & $0.56(0.54 \sim 0.57)$ & $0.55(0.53 \sim 0.56)$ & $0.58(0.56 \sim 0.61)$ & $0.57(0.52-0.61)$ \\
\hline \multirow{4}{*}{ R.T. } & $D$ & $0.43(0.41 \sim 0.45)$ & $0.40(0.38 \sim 0.42)$ & $0.39(0.38 \sim 0.41)$ & $0.40(0.38 \sim 0.42)$ & $0.45(0.41 \sim 0.48)$ & $0.53(0.45 \sim 0.62)$ \\
\hline & I & $0.41(0.38 \sim 0.44)$ & $0.34(0.32 \sim 0.36)$ & $0.32(0.31 \sim 0.34)$ & $0.34(0.32-0.36)$ & $0.33(0.31 \sim 0.35)$ & $0.40(0.34-0.47)$ \\
\hline & $\mathrm{T}$ & $0.84(0.81 \sim 0.87)$ & $0.74(0.72 \sim 0.76)$ & $0.71(0.70 \sim 0.73)$ & $0.74(0.71 \sim 0.77)$ & $0.77(0.73 \sim 0.81)$ & $0.93(0.83-1.04)$ \\
\hline & $\mathrm{D} / \mathrm{T}$ & $0.51(0.49 \sim 0.53)$ & $0.55(0.53 \sim 0.57)$ & $0.56(0.54 \sim 0.57)$ & $0.54(0.53 \sim 0.56)$ & $0.58(0.56 \sim 0.60)$ & $0.57(0.53 \sim 0.61)$ \\
\hline \multirow{4}{*}{ L. M.F. } & D & $0.37(0.32 \sim 0.42)$ & $0.33(0.30 \sim 0.36)$ & $0.31(0.29 \sim 0.33)$ & $0.33(0.30 \sim 0.36)$ & $0.30(0.26 \sim 0.34)$ & $0.48(0.41-0.55)$ \\
\hline & I & $0.46(0.40 \sim 0.51)$ & $0.39(0.35 \sim 0.42)$ & $0.43(0.41 \sim 0.45)$ & $0.45(0.42 \sim 0.48)$ & $0.52(0.48 \sim 0.56)$ & $0.32(0.27 \sim 0.37)$ \\
\hline & $\mathrm{T}$ & $0.82(0.79-0.85)$ & $0.71(0.67 \sim 0.75)$ & $0.74(0.70 \sim 0.78)$ & $0.78(0.74 \sim 0.82)$ & $0.82(0.75 \sim 0.89)$ & $0.80(0.72 \sim 0.88)$ \\
\hline & $\mathrm{D} / \mathrm{T}$ & $0.45(0.41 \sim 0.48)$ & $0.47(0.43 \sim 0.50)$ & $0.42(0.40 \sim 0.44)$ & $0.43(0.40 \sim 0.45)$ & $0.38(0.32 \sim 0.43)$ & $0.60(0.54-0.66)$ \\
\hline \multirow{4}{*}{ R. M. F. } & $D$ & $0.34(0.29 \sim 0.38)$ & $0.31(0.27 \sim 0.36)$ & $0.27(0.24 \sim 0.31)$ & $0.32(0.29 \sim 0.36)$ & $0.27(0.24 \sim 0.30)$ & $0.50(0.42-0.58)$ \\
\hline & I & $0.42(0.38 \sim 0.45)$ & $0.41(0.38 \sim 0.44)$ & $0.44(0.41 \sim 0.48)$ & $0.43(0.38 \sim 0.48)$ & $0.52(0.35 \sim 0.69)$ & $0.36(0.31 \sim 0.41)$ \\
\hline & $\mathrm{T}$ & $0.76(0.69 \sim 0.82)$ & $0.72(0.68 \sim 0.76)$ & $0.72(0.69 \sim 0.74)$ & $0.75(0.71 \sim 0.79)$ & $0.80(0.63 \sim 0.96)$ & $0.86(0.78 \sim 0.94)$ \\
\hline & $\mathrm{D} / \mathrm{T}$ & $0.44(0.42 \sim 0.47)$ & $0.44(0.42-0.47)$ & $0.38(0.33 \sim 0.43)$ & $0.50(0.45 \sim 0.55)$ & $0.34(0.29 \sim 0.39)$ & $0.58(0.53 \sim 0.63)$ \\
\hline
\end{tabular}

注：表7下注参照

差は表 $1 ， 2$ および図 3～10 に示すとおりである.

ます，筋の放電状態については，有歯䪽者18,23)あるい は無歯䫛者21,27 30,36) の各下䫛位における左右の咬筋と 側頭筋について報告されている．著者の $30^{\circ}$ 人工的宷と これらを比較すると, 深水など27 30) は测定装置と测定方

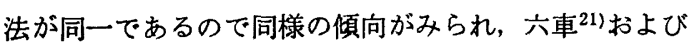
三浦 ${ }^{18)}$ は作業側の咬筋が軽度であるのに対して著者のそ

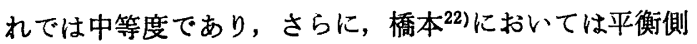
の側頭筋が非活性であるのに対して著者のそれでは軽度 である.このことは咬合力測定時に拉ける偏心咬合位へ の運動量差と指示するかみしめの度合によるものと考え られる. $20^{\circ}$ 人工臼䓲における 4 筋の放電状態は，咬頭 嵌合位および前方咬合位において，30⼈工白歯のそれ とほほ同様であったが，側方咬合位に拉いて $30^{\circ}$ 人工白
歯より強い傾向を示した，側方咬合位における $30^{\circ}$ 人工 臼歯と $20^{\circ}$ 人工正歯の筋の放電活動の差は, 作業側と平 衡側との咬合力値の差に示されるように筋の放電状態に もその差が示されたと考えられる.

4 筋の放電開始をみると各下顎位において，両人工白 歯は 4 筋ともに咬合力の活動開始より早い值を示し, 両 人工臼歯間に有意差は認められない，とくに，咬頭嵌合 位において，4筋の放電開始時間の側差は認められず, 前述の咬合力開始時間の同時性と考えあわせると, 両人 工臼歯はともに下䫑の偏位がなく, 総義歯の最も安定し た状態であると考えられる。

3. ピーナッッ，八ムおよびタクアンにおける各期の 咀嚼力および兽下期の対合力は表 $3 ， 4$ に示すとおりで ある. 
表 $1130^{\circ}$ 人工臼歯のタクアンにおける咀嚼リズムおよび藥下パターン

\begin{tabular}{|c|c|c|c|c|c|c|c|}
\hline & & 期 & 期 & 期 & 期 & 期 & 䓵 \\
\hline \multirow{4}{*}{ L. M. } & D & $0.370 .36 \sim 0.39$ & $0.33(0.31 \sim 0.35)$ & $0.33(0.32 \sim 0.34)$ & $0.36(0.34 \sim 0.37)$ & $0.40(0.38 \sim 0.43)$ & $0.60(0.48 \sim 0.72)$ \\
\hline & I & $0.34(0.32 \sim 0.36)$ & $0.35(0.33 \sim 0.37)$ & $0.35(0.33 \sim 0.36)$ & $0.35(0.33 \sim 0.37)$ & (1). $4 \times 10.44 \sim 0.52)$ & $0.76(0.62 \sim 0.91)$ \\
\hline & $\mathrm{T}$ & $0.72(0.70 \sim 0.73)$ & $0.68(0.66 \sim 0.70)$ & $0.68(0.66 \sim 0.70)$ & $0.71(0.69 \sim 0.74)$ & $0.88(0.83-0.93$ & $1.36(1.15-1.58)$ \\
\hline & $\mathrm{D} / \mathrm{T}$ & $0.54(0.53 \sim 0.56)$ & $0.47(0.45-0.49)$ & $0.49(0.48 \sim 0.51)$ & $0.51(0.49-0.52)$ & $0.45(0.43 \sim 0.47$ & $0.44(0.39-0.49)$ \\
\hline \multirow{4}{*}{ L. T. } & D & $0.40 \div 0.38 \sim 0.41$ & $0.340 .32 \sim 0.36$ & $0.34(0.32 \sim 0.35)$ & $0.34(0.32 \sim 0.35)$ & $0.37(0.35 \sim 0.39)$ & $0.57(0.47 \sim 0.67)$ \\
\hline & I & $0.32(0.30-0.33)$ & $0.33(0.32 \sim 0.35)$ & $0.35(0.34 \sim 0.37)$ & $0.38(0.36 \sim 0.40)$ & $0.50(0.45 \sim 0.56)$ & $0.80(0.62-0.98)$ \\
\hline & $\mathrm{T}$ & $0.71(0.69 \sim 0.73)$ & $0.68(0.67 \sim 0.70)$ & $0.69(0.67 \sim 0.71)$ & 1).72i $0.69-0.14$ & $0.87(0.82 \sim 0.92)$ & $1.37(1.12-1.61)$ \\
\hline & $\mathrm{D} / \mathrm{T}$ & $0.540 .52 \sim 0.56$ & $(0.52(0.50 \sim 0.53)$ & $0.49(0.47 \sim 0.51$ & $0.47(0.45-0.49$ & $0.4330 .41 \sim 0.45$ & $0.43(0.39 \sim 0.47)$ \\
\hline \multirow{4}{*}{ R. M. } & D & $0.41(0.4(1) \sim 0.4 ?$ & $0.35 \div 0.34 \sim 0.36 ?$ & $0.35(0.33 \sim 0 . .36$ & $0.360 .3 .31-0.36$ & (1. 41$)^{\prime} 0.38 \sim 0.412$ & $0.6510 .54 \sim 0.76)$ \\
\hline & 1 & $0.31: 0.30-0.32$ & $0.30+0.28-0.32$ & $0.33 \div(0.31 \sim 0.34$ & $0.35 / 0.33 \sim 0.37$ & $0.46 \div 0.41 \sim 10.51$ & $0.67(0.51 \sim 0.83)$ \\
\hline & $\mathrm{T}$ & $0.72(0.70 \sim 0.74$ & $0.65,0.632 \sim 0.688$ & $(1.68(0.66 \sim 0.70)$ & $0.71(0.658-0.73)$ & $(1 . x(0)(1) .(2) \sim 11.90$ & $1.32(1.09-1.56)$ \\
\hline & $\mathrm{D} / \mathrm{T}$ & $0.5 \times(0.57-0.61)$ & $0.5+11.52-0.56$ & $0.510 .49-0.53$ & $0.51(0.49-0.53$ & $0.470 .44-0.50$ & $0.51(0.47-0.55)$ \\
\hline \multirow{4}{*}{ R. T. } & D & $0.4010 .38-0.41$ & $0.3510 .34 \sim 0.36$ & $0.35(0.33 \sim 0.36)$ & $0.3410 .32-0.36$ & $0.4000 .3 x-0.42$ & $0.60(1.4 \div-0.70)$ \\
\hline & I & $0.32(0.30-0.34$ & $0.330 .32-0.35$ & $0.35(0.33-1) .37$ & $0.370 .35 \sim 0.39$ & $0.77(0.44-0.51)$ & $0.75(0.59-0.90)$ \\
\hline & $\mathrm{T}$ & $0.7160 .70 \sim 0.73$ & $0.68+11.67-0.70$ & $0.7006 .68-0.72$ & $0.710 .69 \sim 0.7 t$ & $0.870 .81-10.94$ & $1.3511 .13-1.59$ \\
\hline & $\mathrm{D} / \mathrm{T}$ & $0.55(0.52 \sim 0.57)$ & $0.51(0.50-0.53)$ & $0.50(0.48-0.52$ & $0.48(0.46 \sim 0.50)$ & $0.470 .45-0.49$ & $(1.48(0.43 \sim 0.52$ \\
\hline \multirow{4}{*}{ L.M. F. } & D & $0.290 .27 \sim 0.32$ & $0.26 \div 0.24 \sim 0.27$ & $0.26(0.25 \sim 0.27)$ & $0.27(0.25-0.29$ & $0.3010 .26 \sim 0.33$ & $0.59(0.43-0.75)$ \\
\hline & I & $0.39(0.37 \sim 0.41)$ & $0.43: 0.41 \sim 0.45$ & $0.430 .41 \sim 0.45$ & $0.47(0.44 \sim 0.50)$ & $0.650 .58-0.72$ & $1.02(0.83 \sim 1.20)$ \\
\hline & $\mathrm{T}$ & $0.69(0.66 \sim 0.71)$ & $0.69: 0.67-0.71)$ & $0.69(0.67-0.72)$ & $0.74(0.71 \sim 0.77)$ & $0.95(0.85 \sim 1.05$ & $1.60(1.34 \sim 1.87)$ \\
\hline & $\mathrm{D} / \mathrm{T}$ & $0.42(0.39 \sim 0.45)$ & $0.37(0.35 \sim 0.39)$ & $0.38(0.36 \sim 0.40)$ & $0.36(0.35-0.36)$ & $0.32(0.30 \sim 0.34)$ & $0.36(0.30 \sim 0.43)$ \\
\hline \multirow{4}{*}{ R.M.F. } & $\mathrm{D}$ & $0.270 .25-0.30$ & $0.27\{0.26 \sim 0.29\}$ & $0.26(0.25 \sim 0.27)$ & $0.27(0.26 \sim 0.28$ & $0.32(0.29 \sim 0.35)$ & $0.67(0.47 \sim 0.87$ \\
\hline & I & $0.40(0.37 \sim 0.43$ & $0.41(0.40 \sim 0.42)$ & $0.45(0.43 \sim 0.47)$ & $0.46(0.43-0.49=$ & $0.64(0.58 \sim 0.70)$ & $1.02(0.83 \sim 1.21)$ \\
\hline & $\mathrm{T}$ & $0.68(0.64 \sim 0.72)$ & $0.68(0.66 \sim 0.70)$ & $0.71(0.68 \sim 0.74)$ & $0.73(0.70 \sim 0.76)$ & $0.96(0.86 \sim 1.06)$ & $1.68(1.35 \sim 2.01)$ \\
\hline & $\mathrm{D} / \mathrm{T}$ & $0.39(0.35 \sim 0.43)$ & $0.40(0.38 \sim 0.41)$ & $0.37(0.35 \sim 0.39)$ & $0.37(0.35 \sim 0.39)$ & $0.34(0.32-0.36)$ & $0.39(0.33 \sim 0.45)$ \\
\hline
\end{tabular}

注：表 7 下注参照

従来, 多くの研究者によって人工臼歯の咬合面形態が 咀噃機能に重大な影響を与えるとされ1 10)，咬合面形態 の理想像が考案開発され ${ }^{1 \sim 10,41)}$ ，さらに，ピーナッッ, ニンジン，八ムなどを用いた多くの報告がある ${ }^{35,42 \sim 53)}$.

著者は破砕性食物としてピーナッッ，弹力性食物とし てハムおよび切断性食物としてタクアンを用いた．著者

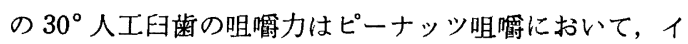
ンダクタンス法の Howell ${ }^{42)}$ とコンデンサー法の三浦 ら ${ }^{47)}$ より各期を通じて $4.3 \sim 10.3 \mathrm{~kg}$ 大きい值を示し, トランスミッター法の坂東 ${ }^{53)}$ より $2.2 \sim 6.0 \mathrm{~kg}$ 小さい值 を示している. 半導体歪素子法の深水 ${ }^{27)}$, 遠藤 29 拉よび 久松 ${ }^{30)}$ とは各食物拉よび各期ともに同じ傾向を示した. 著者の $30^{\circ}$ 人工画歯の対合力は坂東 ${ }^{5)}$, 深水 ${ }^{27)}$, 遠藤 ${ }^{29}$ および久松 ${ }^{30)}$ と同じ傾向を示した.

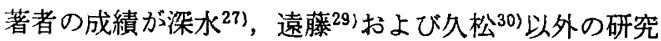
者の値と違っているのは, 深水ら $27,29,30)$ および著者の成 績は各期ごとの成績であるが，他の研究者42,47,53) は咀擸 運動の初期から末期までの全ストロークの平均值を求め ており，咀礵力の変化を見ず，咀嚼運動中のどの期にど れだけの力が働くかを分析していない．第 2 には測定装 置の感度, 第 3 には被験者の条件が設定していないため と考えられる。

咀嚼力および対合力と人工臼歯の咬合面形態との研究 は咬合力の項で述べたごとく，人工臼歯内に埋入しうる 咀礵力測定装置を用いることができず，久松30)とFrechette ${ }^{54)}$ 以外にはみられない。

著者の $30^{\circ}$ 人工臼歯と $20^{\circ}$ 人工臼歯の咀徱力を比較し てみると，食物および期を問わず，前者の方が後者より 
表 $1220^{\circ}$ 人工臼歯のタクアンにおける咀嚼リズムおよび嬹下パターン

\begin{tabular}{|c|c|c|c|c|c|c|c|}
\hline & & 期 & 㻉 & 期 & 期 & 期 & 整 \\
\hline \multirow{4}{*}{ L. M. } & $\mathrm{D}$ & $0.45(0.42 \sim 0.47)$ & $0.41(0.39 \sim 0.43)$ & $0.38(0.34-0.42)$ & $0.46(0.43 \sim 0.49)$ & $0.48(0.45 \sim 0.51)$ & $0.72(0.61 \sim 0.83)$ \\
\hline & I & $0.3 \times(0.36-0.40)$ & $0.3+(0.32 \sim 0.36)$ & $0.36(0.34 \sim 0.38$ & $0.36(0.33 \sim 0.39)$ & $0.37(0.33 \sim 0.41)$ & $0.41(0.33 \sim 0.49)$ \\
\hline & $\mathrm{T}$ & $0.83(0.80 \sim 0.86)$ & $0.76(0.73 \sim 0.79$ & $0.73(0.68 \sim 0.78$ & $0.82(0.78-0.86)$ & $0.85(0.81-0.89)$ & $1.13(0.97 \sim 1.28)$ \\
\hline & $\mathrm{D} / \mathrm{T}$ & $0.54(0.52 \sim 0.56)$ & $0.54(0.52-1) .56$ & $0.54(0.53 \sim 0.56)$ & $0.57\left(0.5 .5 \sim 0.59^{\prime}\right.$ & $0.56(0.52 \sim 0.58)$ & $0.64(0.59 \sim 0.69)$ \\
\hline \multirow{4}{*}{ L. T. } & $\mathrm{D}$ & $0.44(0.41 \sim 0.47)$ & $0.40(0.38 \sim 0.43)$ & $0.43(0.40 \sim 0.46$ & $0.43(0.40-0.47$ & $0.49(0.43 \sim 0.54)$ & $0.57(0.45 \sim 0.69)$ \\
\hline & I & $0.35(0.32 \sim 0.38)$ & $0.35(0.32 \sim 0.37)$ & $0.36(0.34 \sim 0.39)$ & $0.36(0.33 \sim 0.39)$ & $0.40(0.36 \sim 0.45)$ & $0.45(0.37 \sim 0.53)$ \\
\hline & $\mathrm{T}$ & $0.79(0.77 \sim 0.81)$ & $0.75(0.71 \sim 0.79$ & $0.79(0.75 \sim 0.83$ & $0.79(0.76 \sim 0.82)$ & $0.89(0.81-0.96)$ & $1.03(0.89 \sim 1.16)$ \\
\hline & $\mathrm{D} / \mathrm{T}$ & $0.56(0.53 \sim 0.59)$ & $0.55(0.52 \sim 0.57)$ & $0.55(0.52 \sim 0.57$ & $0.55(0.53 \sim 0.57)$ & $0.55(0.53 \sim 0.58$ & $0.56(0.50 \sim 0.61)$ \\
\hline \multirow{4}{*}{ R. M. } & $\mathrm{D}$ & $0.43(0.38-1) .47)$ & $0.40(0.38 \sim 0.42$ & $0.41(0.37 \sim 0.44$ & $0.43(0.41 \sim 0.45$ & $0.49(0.43 \sim 0.55$ & $0.63(0.50 \sim 0.77)$ \\
\hline & I & $0.38(0.35 \sim 0.41$ & $0.36(0.34 \sim 0.39$ & $0.37(0.34-0.40)$ & $0.38(0.35 \sim 0.41$ & $0.41(0.36 \sim 0.45)$ & $0.44(0.38 \sim 0.50)$ \\
\hline & $\mathrm{T}$ & $0.81(0.79 \sim 0.83)$ & $0.75(0.72 \sim 0.78$ & $0.78(0.74 \sim 0.81$ & $0.81 ! 0.77 \sim 0.86$ & $0.89(0.81 \sim 0.97)$ & $1.07(0.92 \sim 1.22)$ \\
\hline & $\mathrm{D} / \mathrm{T}$ & $0.54(0.51 \sim 0.57)$ & $0.50(0.47 \sim 0.53)$ & $0.52(0.49 \sim 0.55)$ & $0.54(0.51 \sim 0.56)$ & $0.54(0.50-0.57)$ & $0.57(0.50 \sim 0.64)$ \\
\hline \multirow{4}{*}{ R. T. } & $\mathrm{D}$ & $0.43(0.41 \sim 0.46)$ & $0.43(0.41 \sim 0.44$ & $0.440 .42 \sim 0.46$ & $0.46^{\circ} 0.43-0.48 ?$ & $0.50(0.46 \sim 0.54)$ & $0.67(0.55 \sim 0.79)$ \\
\hline & I & $0.39(0.37 \sim 0.42)$ & $0.35(0.33-0.37)$ & $0.340 .32 \sim 0.36$ & $0.35(0.32 \sim 0.37)$ & $0.36(0.33-0.40$ & $0.42(0.34 \sim 0.49)$ \\
\hline & $\mathrm{T}$ & $0.820 .79 \sim 0.85)$ & $0.750 .70 \sim 0.80)$ & $0.780 .74 \sim 0.82$ & $0.80) 0.76 \sim 0.85$ & $0.86(0.80-0.93$ & $1.09(0.94 \sim 1.24)$ \\
\hline & $\mathrm{D} / \mathrm{T}$ & $0.52(0.50 \sim 0.55)$ & $0.55(0.54 \sim 0.57)$ & $0.57(0.55 \sim 0.58)$ & $0.58(0.55 \sim 0.61$ & $0.58(0.56 \sim 0.60)$ & $0.61(0.57 \sim 0.66)$ \\
\hline \multirow{4}{*}{ L. M. F. } & $\mathrm{D}$ & $0.31(0.30 \sim 0.33)$ & $0.29(0.27 \sim 0.31)$ & $0.32(0.30 \sim 0.34$ & $0.310 .28 \sim 0.34$ & $0.35(0.32 \sim 0.38)$ & $0.64(0.54 \sim 0.74)$ \\
\hline & I & $0.42(0.40 \sim 0.44)$ & $0.41(0.38 \sim 0.45)$ & $0.44,0.40-10.47$ & $0.430 .39-0.47$ & $0.32(0.28 \sim 0.36)$ & $0.36(0.28 \sim 1.11)$ \\
\hline & $\mathrm{T}$ & $0.73(0.70-0.76)$ & $0.70(0.67 \sim 0.73)$ & $0.760 .72-1) .80$ & $0.750 .70-0.79)$ & $0.67(0.63 \sim 0.71)$ & $1.00(0.89 \sim 1.11)$ \\
\hline & $\mathrm{D} / \mathrm{T}$ & $0.43(0.41 \sim 0.45$ & $0.4110 .38 \sim 0.44$ & $0.4310 .40-0.45$ & $(1.42 \cdot 0.39-0.46$ & $0.52(0.48 \sim 0.56)$ & $0.64(0.59 \sim 0.69)$ \\
\hline \multirow{4}{*}{ R. M. F. } & $\mathrm{D}$ & $0.31(0.29-0.33$ & $0.31(0.29 \sim 0.33)$ & $0.31(0.30 \sim 0.33)$ & $0.29(0.28 \sim 0.31)$ & $0.33(0.29 \sim 0.37)$ & $0.60(0.50 \sim 0.70)$ \\
\hline & I & $0.42(0.40 \sim 0.44$ & $0.4000 .36 \sim 0.43$ & $0.410 .38-0.43$ & $0.43(1) .40-0.46$ & $0.30(0.27 \sim 0.33)$ & $0.38(0.30 \sim 0.46)$ \\
\hline & $\mathrm{T}$ & $0.73(0.70 \sim 0.76$ & $0.72(0.69 \sim 0.76)$ & $0.72(0.69 \sim 0.75$ & $0.72(0.69-0.75)$ & $0.63(0.57 \sim 0.69)$ & $0.98(0.88 \sim 1.08)$ \\
\hline & $\mathrm{D} / \mathrm{T}$ & $0.43(0.41 \sim 0.45)$ & $0.430 .40-0.45$ & $0.44(0.42 \sim 0.46$ & $0.410 .39-0.43$ & $0.52(0.48 \sim 0.56)$ & $0.6 \mathrm{l}(0.56 \sim 0.66)$ \\
\hline
\end{tabular}

注：表 7 下注参照

小さい傾向を示し，曣下期の対合力では逆の傾向を示し た. このことは, 食物, 測定部位および測定装置などに 相違がみられるが，ピーナッッなどの咀啷を $20^{\circ}$ 人工白 歯にて測定した Frechette ${ }^{54)}$ と同じ傾问を示した. $20^{\circ}$

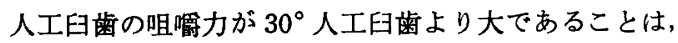
とくに，ピーナッッおよび八ム咀嚼においては $20^{\circ}$ 人工 臼歯の方がピーナッッと八ムの破砕と切截能力が劣って おりこれらをより細かくするために大きな力を必要と したためと考えられる.さらに，著者の成績は $0^{\circ}, 10^{\circ}$ ， $20^{\circ}, 30^{\circ}$ の立体的傾斜を近遠心的ならびに㛲舌的に与え たレジン・ブロックを用いて, 咀嚼能率と咀嚼動作はと もに $30^{\circ}$ のものが最もよいとする津留 ${ }^{55)}$ と同じ傾向を得 た.

これらのことから, $20^{\circ}$ 人工臼歯は $30^{\circ}$ 人工臼菌に比
較して, 総義歯床下軟組織および硬組織への負担が大き くなるものと推察され，枵粘膜の状態，顎堤の大きさと 形態および下顶運動との詷和などを十分考慮する必要が あることを示唆している.

蔡下期の対合力は $30^{\circ}$ 人工正歯の方が $20^{\circ}$ 人工臼歯よ りも大きかった. このことは覚道 ${ }^{56)}$ が述べているよう に, 食物を粉砕しにくい場合, 咀嚼回数を子やして粉砕 するようになるが，咀徱回数は咀嚼習慣により各個人で ほぼ固定されているので, その増加も限度があり, 食物 を粉砕しないまま睘下するために $20^{\circ}$ 人工臼歯の対合力 が小さくなったものと考えられる.

4. ピーナッッ，八ムおよびタクアンの咀嚼過程にお ける，咬筋および側頭筋の放電状態は表 5 12 および図 11〜16 に示すとおりである. 
総義歯装着者の咀嚼時の箭電図所見については, 多く の報告がみられる ${ }^{19,20,27 ~ 30,36,57,58)}$. 著者と比較すると， 咀嚼時に咬筋と側頭筋間に優劣があるとする Schwar$\mathrm{tz}^{57)}$ ，ピーナッッ咀嚼時において，規準義歯の放電振幅 が正常有歯效者より著明な変化を示さないとする津 留 ${ }^{36)}$, Co-ordination pattern にて, 咬笳優勢型 ( $\mathrm{M}$ 型 ストローク）が $79 \%$ であるとする多和 ${ }^{20)}$ およびピーナ ッツ，八ムとタクアンの全期を通じて咬筋は gradual rise and fall 型と側頭筋は recruitment 型を示すとす る深水 ${ }^{27)}$ と久松 ${ }^{30)}$ とほぼ同じ傾向を示している. しか し，咬筋と側頭筋とは咀嚼機能に等しく関与するという Ahlgren ${ }^{58)}$ ，咀灀時に側頭筋の振幅が咬筋より一般に大 きいとする長沢ら ${ }^{19)}$ とは異なっている.

放電持続時間について, 総義柬装着者の深水 ${ }^{28)}$ 执よび 久松 ${ }^{30)}$ は著者の成績と同じ傾向を示しているが, 有歯顎 者 $21,24,58 \sim 60)$ では小さい值を示している. 放電持続時間 が有歯顎者のそれより大きいのは，歯根膜の mechanoreceptor からのインパルスが欠如し，これより感受性 の劣る床下粘膜の圧受容器によって調節されているた め，食物を介在させて欮合した時の感覚刺激が劣り，啮 みしめのための時間が長くなると考えられる.

間隔について, 有歯顎者 ${ }^{21,24,58 ~ 60)}$ は著者とほぼ同程度 かあるいはより大きい値を示す傾向がある，総義歯装着

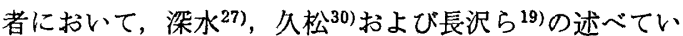
る咀嚼末期における間隔が最も長く，初期より中期が長 い傾向を示すという報告とも一致している.

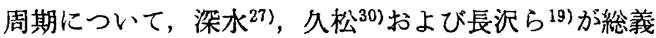
歯装着者の末期で長いと報告していることとほぼ同じ傾 向を示している。

放電周期に対する放電持続時間の割合 (D/T) につい て，著者の成績は有歯影者の咀嚼中の特定期間のみを測 定した値 ${ }^{58 ~ 60)}$ (32〜 41\%) および咀礵開始から睘下まで の全ストロークについて测定した值 ${ }^{21,24,58 \sim 60)}(36 \sim 37$

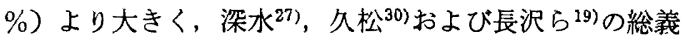
歯装着者とほぼ同じ傾向を示している. 総義歯装着者が 有歯颚者より放電周期に対する放電持続時間の割合が大 きいことは, 咀嗡時に開閉運動の切り換わりが不明瞭 で, 開口時にも閉口筋の放電が持続する ${ }^{36)}$ と考えられ る.

咀嚼リズムについて，30⼈工画の咀嚼時における 筋の放電持続時間，周期および放電周期に対する放電持 続時間の割合は， $20^{\circ}$ 人工四歯のそれらより小さい傾向 を示した.このことは $20^{\circ}$ 人工四歯の場合，筋の収縮時 間がより長いということを示し，また，筋の放電活動も $30^{\circ}$ 人工臼歯より $20^{\circ}$ 人工臼歯が強い傾向を示したのと 合わせて, $20^{\circ}$ 人工臼歯の方が $30^{\circ}$ 人工臼歯よりも放電 活動も強く，持続時間も長くなり，より筋が疲労するも のと考えられる.

$20^{\circ}$ 人工臼歯は臨床上の便宜性を有すると言われてい るが, 咬合平衡, 咀嚼筇の放電様式および義歯床下組織 への影響を考えると，本研究から $30^{\circ}$ 人工臼歯を用いて 患者固有の下顎運動に合わせて，排列および咬合調整を 行った総義歯が最も適切な補緅物であろうと考えられ る.

\section{第 5 章 結 論}

半導体歪素子を応用した咬合力および咀㗖力測定装置 龁代の男性 6 名に，自家調製した $30^{\circ}$ 咬頭人工臼

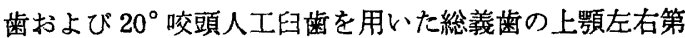
1 大臼歯部に埋入し，各人工臼歯の咬合力および阻緭力 と咬筋と側頭笳筋電図を同時記録し，得られた成績を総 括，検郡して下記の結論に達した.

1. 各下顎位における咬合力は, $20^{\circ}$ 人工白歯の方が $30^{\circ}$ 人工臼歯より小さく，とくに側方咬合位の作業側に おいて有意であった。

2. 各種食物（ピーナッッ，八ムおよよびタアン）で の咀嚼力は, $20^{\circ}$ 人工四歯が $30^{\circ}$ 人工臼歯より大きい傾 向を，嚥下期の対合力は小さい傾向を示した.

3. 各種食物咀嚼時における筋の放電状態は, $20^{\circ}$ 人 工臼歯が $30^{\circ}$ 人工臼歯より大きい傾向を示した.

4. 各種食物の咀嚼リズムは， $1 \sim 5$ 期を通じて $20^{\circ}$ 人工臼歯が $30^{\circ}$ 人工臼歯より大きい傾向を示し，咺下期 では $20^{\circ}$ 人工歯の方が小さい傾向を認めた.

なお，本研究は昭和 52,53 年度日本大学学術研究助 成金により行い，その要旨は第 65 回日本補緅歯科学会 において発表し，会誌に抄録を揭載した.

稿を終わるにあたり，本研究に際し終始ご郎篤なるご 指導およびご校閲を賜わった日本大学中沢靖教授お゙よ゙ 森谷良彦助教授またご専攻の立場からご指導を睗わった 日本大学高下弘夫教授, 西連寺永康教授, 大木一三教授 に深く感謝の意を表します。

あわせて日頃ご助言ご鞭撻を戴いた川口隆彦請師, 深 水皓三助手, 志田啓二助手, 久松正洋助手と本教室の諸 先生および本研究の被験者諸氏に対し感謝の意を表しま t. 


\section{文献}

1) Gysi, A. : Special teeth for cross-bite purpose, Digest, $33: 167 \sim 171,1927$.

2) Sears, V. H.: Specifications for artificial posterior teeth, J. Pros. Dent., $2:$ 353 -361, 1952.

3) Swenson, M. G. : Complete Dentures, 2nd Ed. St. Louis, C. V. Mosby Co., 523, 1947.

4) Hall, R. E. : Full denture construction, J. A. D. A. $16: 1157-1198,1929$.

5) French, F. H. : As we progress, D. Items. Int., $57: 730$ $-741,1953$.

6) McGrane, H.F. : The curved cusp posterior tooth, J. A. D. A., $23: 1072 \sim 1078,1936$.

7) Hardy, I.R. : Technique for use of non-anatomic acrylic posterior teeth, Digest, $48: 562 \sim 566,1942$.

8) Beresin, V. E. : A bio-mechanical approach to the problem of proaethetic occlusion, J. Pros. Dent., 6 : 472 487, 1956.

9) Sosin, M. B. : Re-evaluation of posterior tooth form complete dentures, J. Pros. Dent., $11: 55 \sim 61,1961$.

10) Levin, B.: A Review of artificial posterior tooth forms including a preliminary report on a new posterior tooth, J. Pros. Dent., 38 : 3 15, 1977.

11）橋本僙二：節分法による各種咀哷粉砝試験用食品の比 較について, 口病憙，26:648〜676，1959.

12）石原寿郎他：生米およびビーナッッを試験食品上する

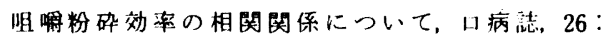
616 622, 1959.

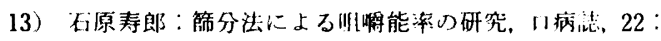
207 255, 1955.

14) Neill, D. J. and Phillips, H. I. B. : The masticatory performance, Dental State and Dietry Intake of Group of Elderly Army Pentioners, Brit. Dent. J., $128: 581 \sim 585,1970$.

15) Farrell, J. H. : Masticatory effect in patient with and without dentures, F. D. I., $14: 226 \sim 237,1963$.

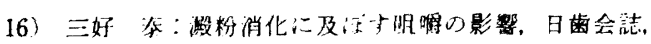
$22: 117 \sim 156,214 \sim 231,1927$.

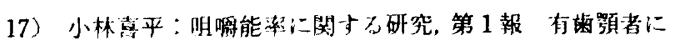
扣计る咀謝に上る殿粉の生化学的消化の基䃈的検討, 日 補棳橉会誌，15，1：27－37，15，2：186２06, 1971.

18）三浦不二夫：筋電図法に上る咀嘎笳の活動様式に関寸

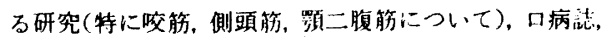
$23: 291 \sim 320,1956$.

19）長讯孛, 高森胃, 津田正昭, 建留宏道: 各種食品咀

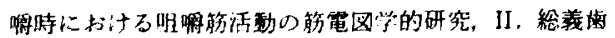

使用者について, 日補経藏会誌，14：120～126，1970.

20)多和伸治：咀㧹時の関口施の EMG Coordination patternについて，日補緅歯会誌，15：48～67, 1971.

21）六車寿男：咀鿟筋筋電図の補緅学的分析に関する研究， 雪科医学， $28: 615 \sim 649,1956$.

22）橋本猛伸：巨圈補緅の効果に関する肪電图学的研究，粀 科医学, $32: 58 \sim 92,1969$.

23）柳田尚三, 加藤 亘, 值手 敏, 松尾悦郎：咀䅨時にお ける咬筋の儌きに関する筋電困学的研究，歯学，44： 16 21, 1956.

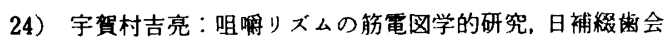
彭， $16: 275 \sim 292,1973$.

25）森谷良彦：総義歯の咬合力に関与る研究補遺，日補緅歯 会誌, $11: 1 \sim 25,1967$.

26）高見沢忠：健常永久歯の相対咬合力および個歯咬合力 に関する研究，日補緅齿会誌，9:217〜236，1965.

27）深水晧三：総義歯の第 1 大臼歯部における咀哷力お上 ひ咬合力に関寸る研究, 日補緅零会誌, $17: 491 \sim 516$, 1974.

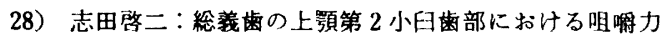
および咬合力に関する研究，日補緅歯会誌，19： 587 610, 1976.

29）遠藤恶史：総義歯にお汁る咬合高径の相違による咀絪 力および咬合力に関する研究, 第 1 報 第 1 大曰橉部に ついて，日補経菊会誌，20：755～772，1977.

30）久松正洋：総義歯に扮ける人工臼歯の咬合面形態の相 違による咀释力扰よび咬合力に関する研究，第 1 報 $\mathrm{O}^{\circ}$ 咬頭人工曰畨について，日補䌡歯会誌，22：15～35, 1978.

31）森行良彦，深水皓三：半導体歪素子を応用した各掬の咬

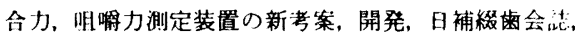
$17: 223 \sim 231,1973$.

32）神野節三：総義幽補緅学，1版，永末書店，京都，45～79. 1964.

33) Manly, R. S.: An Electrbnic Strain Gauge for Measuring oral Forces, J. D. Research, $27: 705 \sim 712$, 1948.

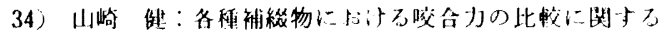

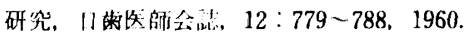

35) Brudevold, F : A basic study of the chewing forces of a denture wearer, J. Amer. Dent. Ass., $43: 45 \sim 41$. 1951.

36）津留宏道：義幽機能に関する生理学的研究，(1)咬合の高 さと義柬機能との関係，日口腔会紤，8：482４96, 1959.

37）沖野節三：有休補緅学，医菌薬出版，東京，119～128, 1968.

38）大不同郎：アーム型分解器とコンデンサ一法に上る下 


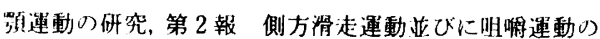
水头面投影に関与る考察，補緅訫，7：196２05，1963.

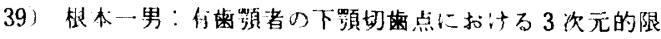

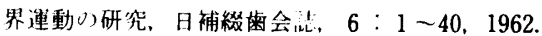

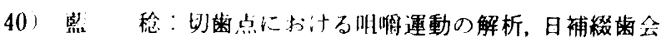
结, $6: 164 \sim 177,1962$.

41) Gysi, A. : Special teeth, Digest, 34:98 103, 182 $\sim 183,1928$.

42) Howell, A.H. and Brudevolt, F. : Vertical Forces Used During Chewing of Food, J. Den. Ress., 29 : 133 $\sim 136,1950$.

43) Rohrbach, C. and Eichner, K. : Massung der krafte beim kauvorgang mit Widerstandsmessdosen von Molarengrosse ohne Behinderung der Okklusion und Artikulation, Dtsch Zahnärzte z., 13 : 146 - 155, 1958.

44) Eichner, K. : Messung der krafte bei Kauvorgangen, Dtsch Zahnärzte. z., 18 : 915 924, 1963.

45) Eichner, K. : Autschlusse uber den kauvorg durch elektronische Kaukraftmessunges, Dtsch. Zahnärtzte. z., $19: 415 \sim 426,1963$.

46) Yurkstas, A. \& Curby, W. A. : Force Analysis of Prosthetic Appliances During Function, J. Pros. Dent., $3: 82 \sim 87,1953$.

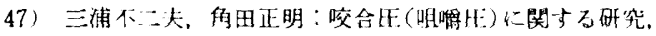
日歯医師会誌， $7: 293 \sim 298 ， 1956$.

48 Anderson, D. J. : A Method of Recording Masticatory Loads, J. Den. Res. 32 : 785 789, 1953.
49) Anderson, D. J.: The physiology of Mastication, Dent. Partitioner, $5: 389 \sim 396,1955$.

50) Anderson, D. J. : Measurement of Stress in Mastication I, J. Den. Res., $35: 664 \sim 670,1956$.

51) Anderson, D. J. : Measurement of Stress in Mastication. II, J. Den. Ress., $35: 671 \sim 673,1956$.

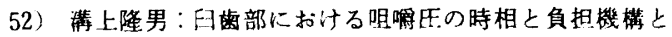
に関寸る研究，料科学報，66:212 272, 1966.

53）坂東永一：口腔機能のテレィターリング，医用䉓子と生 体工学, $7: 281 \sim 288,1969$.

54) Frechette, A. R. : Masticatory forces associated with the use of various types of artificial teeth, J. Pros. Dent., $7: 634 \sim 644,1957$.

55)律留宏道：義機能に関する生理学的研究，(2)咬合面形 態上義菌機能上の関係, 阪大困学誌, $6: 353 \sim 366$, 1961.

56）覚道幸男：床義㐘の生理学, 学建書院, 東京, 147 149, 196 197， 1976.

57) Schwartz, A. M. : Lehrgang der Gebissreglung $z$. Aufl. Urband Schwarzerberg, Wien-Innbruck, 1951.

58) Ahlgren, J. : Mechanism of Mastication, Acta. Scand., 24, Suppl. $44: 1 \sim 109,1966$.

59）川畑衛：各種食品咀㛵時の咀哷笳の積分筋電图につ いて, 歯科医学, $32: 453 \sim 486,1969$.

60）関 秀孝：頡関節症の補緅学的研究，第 2 報，靧関節症 患者の筋電図学的研究，口病誌，35：228～264，1968. 


\title{
Studies on Mastication and Biting Forces of Differences from Occlusal Form of Artificial Posterior Teeth of Complete Dentures Part2. 20 Degree Cusp Teeth
}

\author{
Ryuichi Kagiya \\ Nihon University Graduate School of \\ Dentistry (Major in Prosthodontics) \\ Director : Prof. Yasushi Nakazawa
}

In the complete denture prosthodontics, it has been noticed from old times that the occlusal form of artificial teeth influences masticatory efficiency and basic conditions of its forms have been variously investigated. However, at present there is not always a basis on this point.

By way' of finding out how the occlusal form of artificial teeth has the influence upon the masticatory forces, the masticating forces and forces in the swallowing period at the upper first molars on the complete denture wearers (6 males) from 50 to 59 in age at differences from occlusal form of artificial teeth are recorded at the same time as the electromyography of masseters and temporalis of left and right side.

As the result of these efforts, the following conclusions are obtained.

1. The biting forces in upper first molars of the 20 degree cusp teeth are significantly smaller than 30 degree cusp teeth. Especially in the working side of lateral occlusal position, the former predominates over the latter.

2. The masticating forces in all foods of 20 degree cusp teeth are larger than 30 degree cusp teeth, but on the forces in the swallowing period the former are smaller.

3. As for amount of electoric discharge activity of the masseter and temporalis during masticating each food, 20 degree cusp teeth have a tendency to be larger quantity to 30 degree cusp teeth.

4. Through all periods, the masticatory rythm in all foods of 20 degree cusp teeth have a tendency to be larger 30 degree cusp teeth, but in the swallowing period, the former has a tendency of to be smaller. 